\title{
Funding and founding private charities: Leiden almshouses and their founders, $1450-1800$
}

\author{
HENK LOOIJESTEIJN*
}

ABSTRACT. This article presents a case study of the founders of almshouses for the elderly in the Dutch city of Leiden during the late middle ages and the early modern age. First, an overview of Leiden's almshouses is given and an assessment made of their importance for the elderly. Next, a prosopography of Leiden's almshouse founders is presented, and reasons for founding almshouses discussed, focusing on religion, status, and the support of one's nearest and dearest. This is followed by an analysis of the social class of almshouse inhabitants. This article contends that via almshouse foundations the wealthy and privileged upper classes of Dutch society looked after (distant) family members, employees and other dependants in their patronage orbit, and that almshouses thus in practice served mostly as a respectable way out of open and disgraceful poverty for members of the lower middle class and the class of wage-dependants.

\section{INTRODUCTION}

Dutch charity has been literally monumentalised in a great number of buildings with a charitable purpose, such as hospitals, orphanages and old people's homes as well as almshouses. Frequently, these 'many and various hospitals' were the wonder of foreign visitors such as Sir William Temple, who wrote that these buildings 'are in every man's curiosity and talk that travels their Countrey'. ${ }^{1}$ Many of these institutions were founded and funded with private money. From the late middle ages onwards, wealthy private persons founded hospitals, orphanages, a few madhouses and even an occasional reformatory. ${ }^{2}$ Mostly, however, they established almshouses to allow elderly, honest people of modest means to live out

\footnotetext{
* International Institute of Social History, Amsterdam.
} 
their lives with dignity, preventing their descent into disgraceful poverty through failing strength and diminishing resources. Almshouses were founded in great numbers throughout the early modern age from the late fourteenth century onwards. They could be found in most Dutch cities and even in some villages.

Almshouses for the elderly poor were not confined to the Dutch Republic. They could also be found in, for example, Ireland, England, Belgium, Germany, Denmark, Norway and Italy. ${ }^{3}$ Though almshouses were a recurring feature of charitable endeavour throughout Europe, they have long been neglected as an object of academic historical study. ${ }^{4}$ Nevertheless, enough is known to be able to say that in the Dutch Republic as well as in other European countries, founding an almshouse was an established form of charity amongst wealthy benefactors.

These wealthy almshouse founders have, within the context of the Giving in the Golden Age (GIGA) project, been selected to systematically study what could have motivated the private funding and founding of large-scale philanthropic institutions in the seventeenth century; the Dutch Golden Age. Central questions are: who could afford to spend so much money on a charitable endeavour? Why, and for whom, would one do so? In order to answer these questions, the Dutch Almshouse Database (DAD) has been created. Its purpose is to chart the almshouses established on the territory of the present-day Kingdom of the Netherlands, from the earliest on record until today. Currently, the database contains 563 entries of different Dutch almshouses, giving information such as locality, province, year of foundation and/or termination of the almshouse, number of residents, requirements for residency and on the founders of the almshouses. It is quite certain that more almshouses existed, since many that were short lived tend to be overlooked due to the lack of physical remains or archives. However, sufficient information has been gathered to furnish an overview of when and where almshouse foundations took place in the Netherlands. Figure 1 presents, first, an overview of the 482 Dutch almshouses founded before 1800, before zooming in on the province of Holland, for which most foundations have been recorded, and then concentrating on Leiden, the city that is the focus of this article.

The secondary literature on which the database is based does not always provide all the answers to the research questions. In order to remedy this, the database is supplemented with in-depth case studies based on archival sources. This article presents a case study of the almshouse founders of Leiden and aims to answer the questions: who were these founders, what might have motivated them, and who benefited from their charitable largesse? 


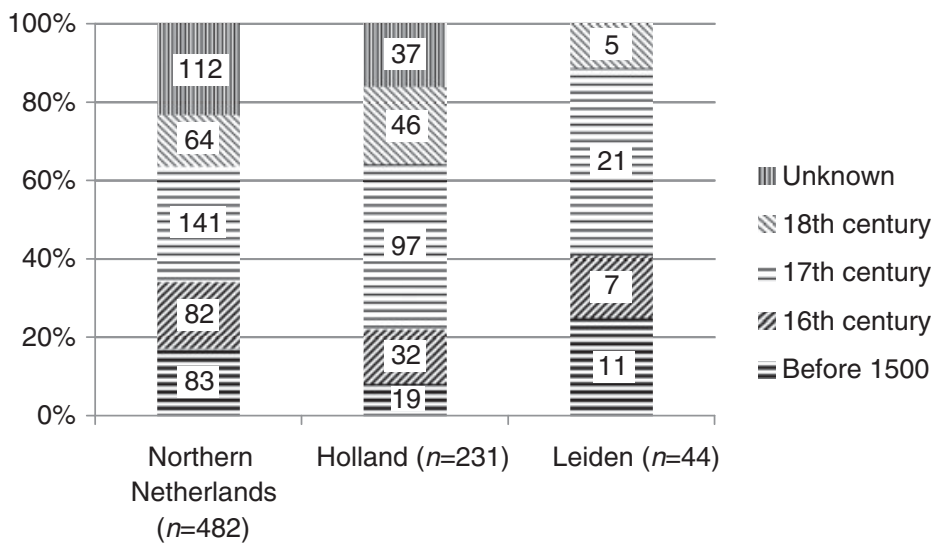

Figure 1. Almshouse foundations in the Northern Netherlands, Holland and Leiden in the centuries before 1800. (Source: Dutch Almshouse Database.)

\section{LEIDEN AS A CASESTUDY}

Leiden was chosen as a case study for various reasons. First of all, Holland was the wealthiest, most highly urbanised and densely populated Dutch province and Leiden, a great industrial city dominating Holland's important textile trade, was the second-largest and the third-richest city of the Republic during most of the early modern age. ${ }^{5}$ Thus, a considerable number of almshouses were founded there. Figure 1 shows how nearly half of the Dutch almshouse foundations took place in Holland, where, as one might expect, the number of foundations peaked in the seventeenth century. Leiden contained a sizeable 19 per cent of all almshouse foundations in Holland before 1800, and foundations there also peaked in the seventeenth century.

Second, since 1955, the 35 almshouses remaining in Leiden have been extensively restored, which has inspired a prolific - if fragmentary and mostly non-academic - secondary literature based around them. In fact, this literature begins with the substantial almshouse descriptions by the Leiden topographers Jan Jansz Orlers (1570-1646) and Frans van Mieris (1689-1762). ${ }^{6}$ In addition, the archives of most Leiden almshouses have survived sufficiently to allow research to be conducted from several angles. In the twentieth century, the upsurge of interest in almshouses and their well-preserved archives has led to considerable attention from both local historians and historians abroad. ${ }^{7}$

Third, Leiden is one of the most profoundly studied urban societies of the early modern Netherlands, which allows us to place the Leiden almshouses and their founders in a context of some depth. 
3. ALMSHOUSES IN LEIDEN: NUMBER, ORGANISATION AND CAPACITY

Though the above-mentioned number of 35 has become a canonical figure in Leiden almshouse historiography, it is certain that more existed: the database currently has 47 entries for Leiden. Nine early foundations - mostly medieval - seem to have been in existence for only a short time and little is known about their founders and history. ${ }^{8}$ They are not considered here. The oldest of the 35 almshouses still in existence is the Jeruzalemshofje, founded in 1467; the most recent, the Justus Carelhuis, was founded in 1936. Most Leiden almshouses date from the four centuries before 1800: almshouse founding was thus mostly a late medieval and early modern phenomenon. Three were founded after 1800 , and fall outside the time limits of our study. Here only the 34 foundations before 1800 about whose founders something conclusive can be said will be discussed.

Appendix Table A shows how these 34 almshouses were essentially founded in two waves; a first wave in the second half of the fifteenth and early sixteenth century, and a second, much longer, wave between 1598 and 1690, coinciding with Leiden's Golden Age. After this peak, almshouse foundations quickly declined in number, especially after the $1720 \mathrm{~s}$. The slumps in founding in the sixteenth and eighteenth centuries are probably related to the severe economic declines that Leiden suffered in these centuries when its predominant industry, textile manufacture, went into recession. Conversely, when Leiden's weaving industry was booming, as in the fifteenth and seventeenth centuries, new almshouses were the fruits of the concomitant prosperity. ${ }^{9}$ This concurs with the findings of Elise van Nederveen Meerkerk that charity markedly diminished when a city went through pronounced economic decline. ${ }^{10}$

Most of the early modern Leiden almshouses were organised along similar lines. Usually founded by a private benefactor, they were destined to house poor, usually elderly, people. Initially, they were mainly founded for and inhabited by couples, later mostly for and by women. Residents enjoyed free housing, along with other benefits, such as regular doles of food, fuel, clothing or money. Sometimes, the almshouse also provided the considerable cost of medicine, health care or a decent funeral. In return, the almspeople were often obligated to sign over their belongings to the almshouse, although this requirement was usually relaxed in the eighteenth and nineteenth centuries. The definition of 'poor' was relative: residents had to conform to certain requirements in order to be eligible for an almshouse, such as having a favourable reputation or being of an appropriate religion. Sometimes residents had to pay a certain amount upon 
entry. Almshouses were, therefore, not open to all poor people. Contrary to popular perception, they may have functioned as safety valves for the lower middle class by allowing elderly people of modest means to enjoy their remaining years with a decent quality of life, a point to which we will return later. ${ }^{11}$

The doles varied in number and in quantity. The contents depended on how much capital the almshouse had at its disposal. Until the twentieth century, this allowance remained part of Dutch almshouse life. The almshouses were run by boards of regents - either as an independent institution or as part of a greater whole, such as the city's almoners' office - who looked after the buildings, the capital and the inhabitants. The regents decided who was to receive a place, and ensured that the inhabitants behaved as honourable, grateful recipients of charity. They also invested the institution's capital and applied for the freedom of taxes that charitable institutions enjoyed.

Before the religious Reformation of the 1570s, most founders in Leiden entrusted their foundation to the colleges of the city's almoners or poor wardens (huiszittenmeesters), who either exercised some manner of supervision or governed the almshouses directly. After the Reformation, by contrast, most founders preferred to create boards of regents either as an independent board unaffiliated with the almoners, or in close cooperation with the particular religious congregation to which they belonged - a consequence of the multiform religious landscape that emerged in Holland after the Reformation. When, in 1582, the Almoners merged with the Dutch Reformed deacons, they were no longer attractive caretakers for other denominations.

In either case, the urban government ensured, by periodical checks and occasional intervention, that the almshouse regents administered the almshouses well and that the latter continued to function as the charitable institutions imagined by their founders. Although most almshouses were founded by private initiative, in an era in which magistrates lacked the means to implement a social housing policy, the Leiden burgomasters kept close watch over what 'social housing' there was. Frequently they were, in a private capacity, on the regent boards themselves. ${ }^{12}$

Despite this close magisterial interest, as a form of 'social housing' almshouses were never more than marginal: by the end of the eighteenth century, Leiden's 34 functioning almshouses offered a total of 562 places. What proportion of Leiden's elderly population could be accommodated in them will be the subject of the following paragraphs.

In the early modern age, old age was thought to begin between 50 and 60 years. ${ }^{13}$ Certain Dutch scholars have estimated that 6 to 8 per cent of the population in the Republic were over 55 years ${ }^{14}$ and others that 
7 to 8 per cent were over 60 years. ${ }^{15}$ The first percentage is certainly too low. Calculations, based on the reconstruction of the demographic regime of Amsterdam between 1680 and 1920 by Marco van Leeuwen and James Oeppen, ${ }^{16}$ show that the percentage of the population over 55 years in Amsterdam was higher: 13.3 per cent in $1680,13.7$ per cent in 1750 and 13.2 per cent in 1795 . They estimate that the percentage of the population over 60 years in Amsterdam was 8.9 in 1680, 7.4 in 1750 and 7.7 in 1795. In another Dutch locality, for which data are available, the village of Maasland, the percentage of people over 60 years shows a different pattern, growing from 4.9 per cent in 1730 to 10.2 per cent by $1800 .{ }^{17} \mathrm{In}$ England the percentage of the population over 60 years grew from 7 per cent in 1581 to between 8 and 9 per cent in the first half and 9 per cent in the second half of the seventeenth century, declining to 8 per cent in the eighteenth century. ${ }^{18}$ If almshouses set an age minimum, they usually set it at 50 years (rather than 55 or 60 years), which would have led to a much larger percentage of the population which could have had access to an almshouse. Assuming that Leiden's demographic regime was similar to that of Amsterdam, this would imply percentages of 18.7 in 1680, 19.9 in 1750 and 18.8 in $1795 .^{19}$

For Leiden, we have no data concerning the percentage of elderly of the total population, ${ }^{20}$ so we will work with estimates based on the total number of inhabitants, using the Amsterdam percentages to calculate the number of elderly. Table 1 shows the numbers and percentages of the total population and the estimated population over 50 years in Leiden in the years 1670,1749 and 1795 , and the number and capacity of the functioning almshouses ${ }^{21}$ in those years.

The percentage of Leiden elderly accommodated in almshouses rose considerably, from 2.7 in 1670 to a maximum of 9.7 per cent in 1795 . The latter number seems to imply that a significant number of Leiden's elderly population resided in almshouses in the late eighteenth century, but a caveat is in order: almshouses in Leiden served more than just the elderly. It has been estimated that in 1749 Leiden's almshouses housed 556 persons. ${ }^{22}$ Many of them were single men and women, widows or couples without children, but there were also couples with children living there. Unfortunately, there are no data that provide the ages of these almshouse inhabitants, but one may assume that at least 49 almshouse inhabitants in 1749 were children. There were also five co-residents of almshouse inhabitants who are likely to have been younger than 50 years - sometimes truly old almspeople had younger relatives caring for them. Both categories amount to 9.7 per cent of the total: the rest - even the parents with children - may well have been over 50 years: 90.3 per cent of the total: 502 persons. ${ }^{23}$ Judging from that number, the number of elderly 
TABLE 1

Number of elderly Leiden inhabitants accommodated in almshouses

\begin{tabular}{lrrr}
\hline \hline & \multicolumn{3}{c}{ Year } \\
\cline { 2 - 4 } & \multicolumn{1}{c}{1670} & 1749 & 1795 \\
\hline Total population & 67,000 & 37,000 & 30,955 \\
Percentage of elderly in total population (estimate) & 18.7 & 19.9 & 18.8 \\
Number of elderly over 50 years (estimate) & 12,060 & 7,263 & 5,820 \\
Number of functioning almshouses & 21 & 33 & 34 \\
Number of places & 325 & 556 & 562 \\
Percentage of population accommodated & 0.5 & 1.5 & 1.8 \\
Percentage of elderly accommodated & 2.7 & 7.7 & 9.7 \\
\hline \hline
\end{tabular}

Sources: Population 1670 and 1795: Piet Lourens and Jan Lucassen, Inwoneraantallen van Nederlandse steden ca. 1300-1800 (Amsterdam, 1997), 113-14. Population 1749: D. J. Noordam, 'Gezins- en huishoudens-structuren in het achttiende-eeuwse Leiden', in H. A. Diederiks, D. J. Noordam and H. D. Tjalsma, Armoede en sociale spanning. Sociaal-historische studies over Leiden in de achttiende eeuw (Hilversum, 1985), 87-104, especially 88. Percentage of elderly in total population based upon Amsterdam figures. Almshouses: Dutch Almshouse Database (DAD). Places: DAD. For 1670 the number is deduced from the number of inhabitants or apartments specified in the founding acts. In some cases, the number of inhabitants would have been higher than the number of apartments, but that is not always clear from the sources. Moreover, under-registration was common because almshouses sometimes allowed more inhabitants than originally specified. This number must, therefore, be regarded as an approximate minimum. 1749: Tjalsma, 'Een karakterisering van Leiden', in Diederiks, Noordam and Tjalsma, Armoede en sociale spanning, 33.

almshouse inhabitants in 1749 was not 7.7 but more like 6.9 per cent of the total number of Leiden inhabitants over 50 years. Extrapolating to 1795, when there may have been as many as 562 almshouse inhabitants, of which - if the structure was the same as in $1749-507$ may have been over 50 years, instead of 9.7 the proportion might have been about 8.7 per cent of the Leiden elderly. These figures must, however, be regarded as tentative. Nevertheless, even with these lower estimates, almshouses were significant as a particular poor relief institution for the elderly. Their importance continued to grow throughout the early modern age, mainly due to the decrease in the population of Leiden, assisted by a slight increase in almshouse places. Eventually, almshouses catered for up to a third of the total number of elderly in need of care; other types of care for the Leiden elderly each seem to have supported smaller numbers of people. ${ }^{24}$

\section{LEIDEN ALMSHOUSE FOUNDERS: A TENTATIVE PROSOPOGRAPHY}

It is time to return to the first research question: who were the founders of the Leiden almshouses? To help understand what might have motivated 
almshouse founders over such a long stretch of time, data have been gathered which form building blocks of a prosopography of almshouse founders: their names, dates, social status, occupations, wealth, gender, family relations (i.e. whether they were married, single and had children or not) and religion. The method of prosopography is, in itself, insufficient to isolate motives for founding almshouses, but allows the shared characteristics of almshouse founders to be established. In some cases such as with the absence of children - such information may lead to the identification of a particular motive amongst founders. ${ }^{25}$

The Leiden case study is based on 34 almshouse foundations, enumerated in Table A in the Appendix, which lists the foundations, their founders (36 in all), ${ }^{26}$ the dates of original statement of intention to make a foundation and the dates that the foundations were actually effected. ${ }^{27}$ The founders and their characteristics are listed in Table B in the Appendix, which includes such items as each founder's gender, marital status, occupation, religion, presence or absence of offspring, the highest public office - if any - held in Leiden, and whether they were of immigrant descent. All of these will be discussed in the following paragraphs.

Of the 36 founders, 23 acted alone. Of these individuals, 17 were men and six were women. This did not mean that they were all unmarried: sometimes their partner did not take part in the foundation. There were also nine married couples acting as joint founders, while the Hofje van Brouckhoven and the Tevelingshofje were founded by siblings. The largest group of founders, thus, consisted of male founders acting alone, the second largest comprised couples and the smallest female founders. Nevertheless there was a significant percentage of single women founders: six women out of 23 (26 per cent) may exemplify the great liberty which Dutch women enjoyed when it came to dispensing with their property. ${ }^{28}$ For example, the Klein Sionshofje was founded in 1641 by Emerentia Benningh (founder number 17 in Appendix Table B) while her husband Jacob van Brouckhoven (16a) was still alive. Since he had founded his own almshouse, following the last will of his sister, he may have supported his wife's endeavour without feeling the need to act as a co-founder.

At the time of foundation, 17 founders were married, ${ }^{29}$ a further 10 had been widowed and five had never been married. The exact marital status of four other founders at the time of foundation is unknown. In three of these cases, it is known that François Houttijn (28), Samuel de Zee (31) and Barend van Namen (32) were married at some point, but it is unclear whether they were still married at the time of foundation. Even if the last unknown case, Joost Fransz van der Linden (25), remained unmarried all his life, the vast majority of founders, 30 out of 36 , were married at some stage. 
The majority - 26 out of 36 - of founders did not have any surviving children at the moment of foundation. At least 15 founders are known to have been completely childless. ${ }^{30}$ In a further six cases, the records do not mention childlessness, but no children are known. In another five cases, their children had predeceased the founders. Nothing is known about the children of the final founder, Joost Fransz van der Linde, but it is likely that he did not leave behind any as living heirs. The nine remaining founders had children living at the time of foundation.

The absence of children seems to have been a crucial factor in the decision to contribute to charity on a grand scale. The prime consideration and obligation of an ageing, early modern Dutchman was to transfer his property to his partner, children or other descendants. If these were absent, he had a certain moral liberty to dispense with part of his capital for the benefit of people to whom he was not related. This 'unwritten rule' also applied to bequests, which in Leiden were given predominantly by people without children. ${ }^{31}$

Nevertheless, in nine of the cases under consideration, the founders had children who were alive when the almshouse was founded. In the case of Jacob Tevel and Elisabeth van den Vinct (22b) their only son was severely handicapped and clearly expected to die young, which he duly did. Two other foundations were to be realised only if a child died. The foundation by Bartolomeus Willemsz van Assendelft (13) was only to take effect if his daughter or her descendants were to die without heirs of the body, ${ }^{32}$ an eventuality which occurred in 1681, nearly 56 years later. François Houttijn stipulated in his will that after the death of his daughter and brother, an almshouse should be founded. Both died, without descendants, within three years of Houttijn, after which the foundation took effect.

Only six founders apparently had healthy children who lived long beyond their parents and had descendants. ${ }^{33}$ Of these founders, four lived before Leiden's Reformation in 1573 . They were all wealthy and, perhaps, considered their children well taken care of already. The same applies to two of the later founders, Gerrit Franckensz van Hoogmade (15) and Diderick van Leyden (33). Van Leyden, an exceptionally proud patrician, even in the eyes of his peers, ${ }^{34}$ not only founded the Mierennesthofje in Leiden, but also, in 1757, the Van Leydenshofje in his lordship, Vlaardingen. Van Leyden was exceedingly wealthy and had bequeathed a string of local lordships to his surviving sons, so that none of them needed to worry about being disadvantaged on account of their father's philanthropic largesse. Indeed, they faithfully administered his foundations. ${ }^{35}$

As for religion, all eight pre-Reformation founders must be considered Catholics as, until 1573, the Catholic church was the only recognised 
church. After 1573, religious diversity emerged in Leiden, and most of the 28 post-Reformation founders were Protestants of some description, while only four were Catholic, two were Remonstrant and one was Mennonite. The remaining 21 Protestant founders belonged to the Reformed church, either the public, Dutch Reformed church or the French-speaking Walloon Reformed church. Theologically, these churches were in communion with each other, and the Walloons belonged to the officially accepted Calvinist Reformed church.

These data on Leiden founders can be compared with all the founders in the database. The results are presented in Table 2.

At face value, the Leiden data differ considerably from the whole. However, research in Leiden's archives has supplied data lacking for other localities, so there is a contrast with the larger database where there is a considerable percentage of cases where data are unknown. For example: in 45 per cent of cases marital status is unknown, in 71 per cent it is not known if the founder had long-lived progeny, and in 29 per cent of cases no indication of religion was available.

Nevertheless, there are also similarities between the data for the Northern Netherlands and those for Leiden. As in Leiden, nearly half of the founders in the Northern Netherlands were men acting alone, most of those about whom something is known were married at some point and most were childless or their children had predeceased them. It is probable therefore that the Leiden data are representative of the larger database, but this can remain no more than a tentative conclusion. Table 2 suggests that outside Leiden a greater proportion of founders were single females, whereas the proportion of founders who were couples was much lower. This difference may again be a result from the additional archival research undertaken in Leiden, which supplied the names and identified the existence of partners of the Leiden almshouse founders.

There were clear differences where religion was concerned, which is probably due to the uneven distribution of the religious groups. Catholicism, for example, was much stronger in cities such as Amsterdam and Haarlem, and the database shows more Catholic foundations in these cities after the Reformation.

There are fewer data on the wealth of founders - even in the case of Leiden despite the extra archival research there. Often there is insufficient source material to assess either the wealth held by the founders or what proportion of it they spent on their foundation.$^{36}$ Older foundations in particular were often not funded in terms of money, but were endowed with lands and houses, from which the foundation was to receive rents necessary for its upkeep. ${ }^{37}$ Sometimes, as founders already owned the 
TABLE 2

Leiden founders compared with founders in the Northern Netherlands as a whole

\begin{tabular}{|c|c|c|c|c|}
\hline & \multicolumn{2}{|c|}{ Leiden } & \multicolumn{2}{|c|}{ Northern Netherlands } \\
\hline & $n$ & $\%$ & $n$ & $\%$ \\
\hline \multicolumn{5}{|l|}{ Type of founder } \\
\hline Male single & 17 & 47 & 175 & 46 \\
\hline Female single & 6 & 17 & 91 & 24 \\
\hline Couple & 9 & 25 & 55 & 15 \\
\hline Other & 4 & 11 & 58 & 15 \\
\hline Total & 36 & 100 & $379^{\mathrm{a}}$ & 100 \\
\hline \multicolumn{5}{|l|}{ Known marital status } \\
\hline Married at one point & 30 & 86 & 160 & 77 \\
\hline Never married & 5 & 14 & 48 & 23 \\
\hline Total & 35 & 100 & 208 & 100 \\
\hline \multicolumn{5}{|l|}{ Known offspring } \\
\hline No surviving offspring & 29 & 83 & 74 & 69 \\
\hline Surviving offspring in the long term & 6 & 17 & 34 & 31 \\
\hline Total & 35 & 100 & 108 & 100 \\
\hline \multicolumn{5}{|l|}{ Known religion } \\
\hline Catholic & 12 & 33 & 188 & 70 \\
\hline Dutch Reformed & 13 & 36 & 42 & 16 \\
\hline Walloon Reformed & 8 & 22 & 8 & 2.5 \\
\hline Remonstrant & 2 & 6 & 8 & 2.5 \\
\hline Mennonite & 1 & 3 & 13 & 5 \\
\hline Other & 0 & 0 & 10 & 4 \\
\hline Total & 36 & 100 & 269 & 100 \\
\hline
\end{tabular}

${ }^{a}$ Number of almshouse founders before 1800 in Dutch Almshouse Database about whom at least some data are known.

Source: Dutch Almshouse Database.

buildings that were to form their almshouse, they granted a sum of money only for upkeep. Cathrijn Maertensdr (10) left 600 guilders for the upkeep of her almshouse while Pieter Gerritsz van der Speck (18) bequeathed 4,000 guilders to his. ${ }^{38}$ Sometimes, we are informed about how much money the founders intended to set aside, but not how much the total capital was, such as in the case of Eva van Hoogeveen (20), who left obligations (bonds) worth 32,000 guilders for her almshouse, a sum which was indeed spent, but which was considerably lower than the amount inherited by her family. ${ }^{39}$ Sometimes we know how much was spent but not the total wealth of the founder. Diderick van Leyden spent 1,055 guilders buying the houses that would become the Mierennesthofje. 
In 1760 he bequeathed 9,300 guilders in obligations to this almshouse. ${ }^{40}$ Cecilia Coninck (34) reserved 50,000 guilders for her almshouse, of which 13,000 was spent on the actual building. ${ }^{41}$

In a few cases, we can assess how much of their capital founders spent on their foundations. Jacob van Brouckhoven (16a), who built and founded his almshouse during his lifetime, possessed 250,000 guilders in 1626 . He spent approximately 20,000 guilders on his foundation $^{42}$ - less than a tenth of his total capital, but nevertheless a considerable amount. Cornelis Sprongh (30) spent even more in terms of percentage of his total wealth. He left half of his estate - worth 109,365 guilder $^{43}$ - to the almshouse to be situated in his house. Joint founders Jean Pesijn and Marie de Lannoy (23) spent their entire capital on their almshouse. In 1674, as a widow, de Lannoy was estimated to possess a capital of 25 to 26,000 guilders. After her death and the sale of all her possessions, the total capital came to 27,642 guilders. This entire amount was spent on building the almshouse and acquiring the obligations whose rents were to provide for the upkeep of the Jean Pesijnshofje. ${ }^{44}$

To put all these sums into perspective, in the years 1700-1780, the average capital of a Leiden town regent was 154,159 guilders; of a regent's relative 99,$770 ;^{45}$ the average capital of a merchant/entrepreneur was 253,782 guilders; a rich Catholic, 149,457 guilders; and a Protestant rentier, 305,796 guilders. ${ }^{46}$ Thus, the amount available to spend on founding an almshouse varied considerably. Evidently, not all founders spent the same amount, or even the same proportion of their total capital on their almshouse. Certainly, in the case of the larger almshouses, a large amount of capital was required and founding an almshouse could considerably drain one's resources.

Because the data concerning wealth are often insufficient, the occupations of the founders, as possible indicator of wealth, and social class, as captured via membership of the patrician elite, have been singled out in two columns in Appendix Table B. Some occupations are likely to function as good indicators of wealth: brewer, merchant, landed proprietor, ${ }^{47}$ administrator, ${ }^{48}$ director of the Dutch East India Company and lawyer. However, occupations as such are not necessarily a reliable indicator of wealth. Thus, the husbands of both Cathrijn Jacobsdr (9) and Cathrijn Maertensdr (10) were tailors, a relatively modest occupation in itself. Secondary sources, however, describe the husband of Cathrijn Maertensdr as a 'rich' tailor. The same applies to 'carpenter' Pieter Gerritsz van der Speck (18), whose relatively modest occupational title hides the fact that he was active as a successful contractor and speculator who earned his fortune in Leiden's building boom of the early 1600s. 
The same applies to Anthonis Jacobsz van der Schacht (24), listed as shopkeeper, but whose probate inventory shows that he actually owned 28 houses in Leiden. ${ }^{49}$

We may, therefore, assume that even when an occupational title is fairly modest, the founder in question nevertheless enjoyed considerable success and wealth. This does not mean, however, that they necessarily enjoyed high social status in Leiden - they may have been homines novi or 'new men' - a term which may also have applied to many of the merchants. The apex of Leiden society, as in all Dutch cities, was occupied by the town regents, who were co-opted into the urban government. ${ }^{50}$ Participation of the almshouse founders in the city's government provides another indicator of status. Only a minority of the founders were town regents, mostly in the years around and before 1500, when two founders reached the rank of alderman, and three that of burgomaster. Although the other two pre-Reformation founders were not members of the city government, Agatha van Alckemade (7) and Geraert van der Laen (8), enjoyed high social status. Van Alckemade was a noblewoman of high rank and Van der Laen was a major landed proprietor, so equal to a lesser nobleman.

After the Reformation, however, the number of patricians and noblemen among the founders in Leiden declined considerably. ${ }^{51}$ Of 28 such founders, only three were members of the city council. Two of these, Jacob van Brouckhoven (16a) and Diderick van Leyden (33), were quite exceptional among their peers on account of their great wealth, status and considerable power. ${ }^{52}$ There were, however, six other founders affiliated with the city's patrician elite and therefore of high social status: the sister and wife of Jacob van Brouckhoven; the Catholic priest Pouwels Claesz de Goede (14), member of a former magistrate's family; Eva van Hoogeveen (20), daughter and sister to magistrates; Maarten Ruychaver Meerman (27), brother of a magistrate; and Cornelis Sprongh (30), a Catholic descended from a distinguished magistrate's family whose great wealth meant that he was regarded as socially near-equal to his Protestant relations.

Even when counting these six individuals in, only nine out of 28 postReformation almshouse founders can be regarded as part of Leiden's highest social stratum, which contrasts strongly with the fact that all eight pre-Reformation founders were of such status. ${ }^{53}$ The contrast between the status of almshouse founders before and after the Reformation begs explanation. It would appear that after the Reformation most town regents of Leiden preferred not to display charity through the foundation of almshouses. ${ }^{54}$ As the number of elderly far exceeded the available almshouse places, the city was always in need of an extra almshouse. 
Nevertheless, though there were significant accumulations of capital in eighteenth-century Leiden and, at the same time, an ever-growing part of the population was mired in poverty, only one regent founded an almshouse; charity does not seem to have ranked high on the list of Leiden town regents' concerns. ${ }^{55}$ Van Nederveen Meerkerk, incidentally, notes that in Leiden, most testamentary bequests were not made by the elite but by the 'middling' groups. ${ }^{56}$ There are a few exceptions, however, which show that patricians occasionally acted charitably on a grand scale and were wealthy enough to found an almshouse should they choose to do so. The alderman Pieter Verhooft and his wife, Elisabeth van der Hiel, bequeathed 20,000 guilders to the city orphanage in 1740 . They could have afforded to found an almshouse, but the charitable couple had no desire to have their charity publicly remembered, desiring an 'eternal silence' on the subject of their largesse. ${ }^{57}$

Before lambasting Leiden's regents as Scrooges however, one should take into account that many town regents, in addition to their public magistrate functions, also often acted as lifelong regents of the various almshouses in Leiden. For example, all eighteenth-century regents of the Hofje van Brouckhoven were until 1795 also members of the city council. ${ }^{58}$ They often took on several almshouse regent positions. To give just one example, burgomaster Nicolaas van de Velde (1697-1773) was regent of three almshouses. ${ }^{59}$ Those of high social status thus held a considerable number of almshouse regencies. Qualitative evidence suggests that the regents of almshouses often contributed their own funds to the upkeep and continuation of the almshouses they administered. They left bequests to them, compensated for deficits in the accounts and spent money on their beautification. Evidence from Amsterdam suggests that having given great sums to charity during their lifetime, they might then have been less able to be charitable after death. ${ }^{60}$ Regents were also often related to people who founded almshouses, and were expected to look after these foundations out of familial respect and piety. Thus those resources for charity which they had, they were likely to channel into already existing almshouses. Diderick van Leyden (number 33 in Appendix Table B) not only founded two almshouses, but also acted as regent of the Hofje van Brouckhoven as well as passing on to his sons no less than two regent posts in the Arend Maertenshofje in Dordrecht - founded by a great-grandfather of his-suggesting that he was an extraordinary exception that confirms the rule. ${ }^{61}$

This all suggests that founding an almshouse, at least after the Reformation, was more the work of a social sub-elite, a layer lower than the city's patrician families. We will return to this analysis in the following section. 


\section{REASONS FOR FOUNDING ALMSHOUSES}

Like most people, almshouse founders seldom acted out of one overriding motive, but rather from a mixture of motives. Limitations of space prohibit a discussion of the whole range of possible motives. Instead, we will focus on three important motives: religion, status and the motive of supporting one's nearest and dearest. ${ }^{62}$

\subsection{Religion}

The earliest almshouse foundations were presumably the result of primarily religious motives; the wish to attain salvation through charitable work. In the late middle ages, many gifts to the church and institutions of poor relief were given under the condition that they should be acknowledged by the recipients in the form of prayers for the benefactors. At the time, people commonly adhered to the Church's doctrine that, after death, the soul entered Purgatory to be cleansed of its sins until it was fit to enter Heaven. Intercession in the form of prayers quickened the purification process, especially when the prayers came from devout and poor people. The acquisition and possession of wealth implied a greater burden of sin, but the rich sinner could lighten his burden by charitable acts, which had the added benefit of instilling gratitude in the recipients, who responded by praying for the benefactor.

One of the forms in which this pursuit of salvation could be given shape was the bedehouse. A benefactor would found an almshouse, preferably for 12,13 or 14 inhabitants - holy numbers referring to Mary, Christ and the twelve apostles - where poor people, usually elderly, were given free housing and often additional benefits. In return, these almspeople were to pray for the founders in perpetuity, either in the almshouse chapel or in a church. In Leiden, both the Jeruzalemshofje and the Sint Anna Aalmoeshuis had their own chapels, the latter surviving to the present day ${ }^{63}$ and the residents were expected to pray for the founders. The other early almshouses also acted as bedehouses. The founders of the Sionshofje, Sint Stevenshofje, Sint Annahofje and the Sint Janshofje all stipulated that prayers should be said for them. ${ }^{64}$ Thus, personal salvation was clearly a motive for the earliest six foundations, but seems to have lost its attraction by the 1560s, even for devout Catholics such as Agatha van Alckemade (number 7 in Appendix Table B), who founded the Bethaniënhofje for the benefit of her soul and that of her parents, but did not require prayers. ${ }^{65}$ Vestiges of this memorial cult seem, nevertheless, to have persisted in some way among Catholics. Pouwels de Goede (14) stipulated, in 1625, that his portrait should be displayed in his eternal memory in the almshouse that he had founded. ${ }^{66}$ Cornelis Sprongh (30) stipulated, in 1690, 
that the almswomen in his Heilige Geesthofje were to be given a treat on the anniversaries of his birthday and that of his wife. ${ }^{67}$

With the advent of the Reformation, religious motivation becomes harder to identify. Protestant theologians often rejected the belief that good works could lead to salvation. Thus, almshouse foundation could no longer be regarded as particularly beneficial for the soul. Undoubtedly, not all formally Protestant founders were fully immersed in the finer points of their church's theology and may yet have hoped for some heavenly reward. ${ }^{68}$ However, it is known that some founders, such as Jacob van Brouckhoven (16a), were well versed in orthodox theology. It has been suggested that for orthodox Calvinists, founding an almshouse was a public assertion of confidence in their salvation and of thankfulness for God's merciful - and undeserved - bestowal of so much material wealth. This was, presumably, the case with the founders Van Brouckhoven, who was a thrifty and militant Calvinist, ${ }^{69}$ Catharina Geschier (29), who, in her will, wrote that 'the blessing of the Lord makes rich without labour', ${ }^{70}$ and Samuel de Zee (31), whose will shows great zeal for the Calvinist faith, founding two scholarships for theology students and arranging for the inhabitants of his almshouse to receive catechism lessons every week. ${ }^{\mathbf{1 1}}$

\subsection{Memorial cult and social status}

Whereas prayers for the dead lost their urgency in Protestant theology, the cult of commemorating the charitable dead did not disappear after the Reformation. If anything, it became stronger, for though religious piety might have found new channels to express itself, familial piety lost nothing of its attraction. In fact, the charitable foundations of their ancestors seem to have become more important for the founders' families, with the emphasis shifting to the memory of the family as such. Almshouses that were run by generations of the same family could develop into monuments to familial charity, ${ }^{\mathbf{7 2}}$ veritable family shrines. This concern seems also to have become more important for the founders themselves, who sometimes specified that their portraits - and sometimes those of their predeceased offspring - be placed in the regent chambers. ${ }^{73}$

This new form of memorial cult was translated into the rise of elaborate gatehouses, fitted out with coats of arms and commemorative inscriptions. Jan Willemsz van Woudendorp (19), for example, described in detail his coat of arms in his will, which was to be displayed over the gate. ${ }^{74}$ Anthonis Jacobsz van der Schacht (24) had the gate of his almshouse decorated with depictions of the tools of his trade. Incidentally, the placing of coats of arms was not the exclusive domain of almshouse founders. Leiden town regents, from the seventeenth century onwards, also placed 
their coats of arms on many public and semi-public buildings. ${ }^{75}$ For them, founding an almshouse was not the only road to an increase in status and honour of their family.

In the second half of the seventeenth century a subsequent phase in the history of Dutch almshouses began, the building of so-called 'monumental' almshouses. Founders were no longer content with reasonably modest buildings but, as well as impressive gatehouses, built lavish regents' chambers and courtyards with monumental wells. These provided the inhabitants with more living space than the older almshouses. Prominent monumental almshouses in Leiden are the Hofje van Brouckhoven and the Hofje Meermansburg. The latter was described as more pleasant than an imperial palace ${ }^{76}$ and functioned as a monument to the charity of the Meerman family as much as an almshouse, with coats of arms on the outside and a well topped by their eponymous merman. Similarly, the Hofje van Eva van Hoogeveen was adorned with a coat of arms on the outside wall and the well was topped by a statue of a lamb, referring to the lamb in the family coat of arms. Obviously, charitable purposes could be combined with the exaltation of one's family.

It is difficult to see how this rise of monumental almshouses could be compatible with the Calvinist theology dominating the Dutch Reformed church, which warned against excessive external display. Jacob van Brouckhoven, whose orthodox Calvinism is beyond doubt, also had his coat of arms displayed on the impressive gatehouse to his almshouse, though he did not go so far as to have his full name recorded. Instead, the only inscriptions are his and his co-founders' initials. Even to committed Calvinists, it would seem, the honour and status of the family were important concerns. ${ }^{77}$

The fact that many almshouse founders were childless and their almshouses were often completed only after their death does not contradict the importance of this concern. The reputation and status of one's family was not only determined by the present, but also, greatly, by the past. ${ }^{78}$ Even if one was the last of the line, one still had obligations to the familial memory by making sure that a family name would not be forgotten even after its extinction.

There are more reasons to assume that status acquisition played a role. This may be deduced from the fact that so many post-Reformation founders in Leiden were immigrants, a trait possibly peculiar to almshouse founders in this city given the enormous influx of French-speaking immigrants from the Southern Netherlands. At least seven foundations were the work of eight founders who were immigrants - or children of immigrants - from the South. ${ }^{79}$ Though often very successful in their new home city, none of them ever achieved the highest social status in the form 
of a position on the city council. This reflects the notorious tendency of Leiden's elite to close its ranks against the Southerners and politically exclude the migrant minority ${ }^{80}$ Most of these Southerners, though not all, were members of the Walloon Reformed congregation and, thus, attended a church in a different linguistic environment from that of their indigenous co-religionists. For this sub-elite group in Leiden, status acquisition, coupled with a desire to strengthen their own (ethnic) community, may well have been a strong motive for founding an almshouse.

\subsection{Care for one's dearest}

Many founders felt concerned for the generations who would come after them and part of maintaining the honour of the lineage was the duty to care for family members. It has been said that the almshouse founders and regents probably intended to safeguard from social decline less successful members of the same social group that they themselves belonged to, especially their family members. ${ }^{81}$ Thus, not only was the memory of the family safeguarded, but the almshouse also protected the family's status even if one of the members had hit hard times. This not only applied to those who shared the family name of the founder, but to a much wider circle of kin. It is difficult to trace such relations, since almshouse administration was often rather haphazard. If a distant family relationship was a reason for giving a particular person a place, it was not always recorded, and even if it was, the precise kinship relation to the founder was rarely specified. Given the fact that founders frequently made this explicit proviso in their will, however, it is likely that this was a motive of some importance. ${ }^{82}$

Once again this was a motive dating from the late middle ages: explicit provisions that almshouse administrators should give preference to family members date from long before the Reformation, as in the case of the founders of the Sint Anna Aalmoeshuis and the Sint Stevenshofje. Moreover, it was no empty stipulation. The Sint Anna Aalmoeshuis, for example, housed two women from amongst the founder's kin between 1606 and $1626 .{ }^{83}$ Jan Willemsz van Woudendorp (19 in Appendix Table B) also stipulated that precedence should be given to his kin. Though most of his near family were wealthy enough not to need a place in his almshouse, one line was impoverished, and throughout the seventeenth and eighteenth centuries could dependably acquire a place in his almshouse. ${ }^{84}$ Similarly, the almshouse of Samuel de Zee (31) was explicitly set up and referred to as a 'family almshouse'. ${ }^{85}$ At least until the mid-nineteenth century, the regents kept detailed records of who was entitled to a place in the almshouse. Overall, regents scrupulously adhered to such rules, even 
centuries later: for example, the regents of the Sint Stevenshofje, founded in 1487 , on two occasions, in 1744 and 1783 , specifically stated that they had admitted a person because he was of the founder's kin. ${ }^{86}$ The founders of Meermansburg specified not only that their family enjoyed precedence, but even assigned a specific apartment in their almshouse to be kept available for family members at all times, and which was indeed used for that purpose, although on occasion it was uninhabited. ${ }^{87}$

Sometimes the almshouse regents themselves fell into poverty and had to make use of these stipulations privileging family. This happened to the Van der Laens, regents of the Sint Janshofje, by the end of the seventeenth century. One of the Van der Laen regents, an impoverished widow, took a place in the family almshouse. The last Van der Laen took advantage of her kinship with the Meermans and died as an inhabitant of the family apartment in the Hofje Meermansburg. ${ }^{88}$

\subsection{Care for one's nearest}

Even if a founder often favoured his (or her) own kin over others, he ordinarily assumed in his will that kin would not be the sole beneficiaries of his charity. Usually founders described the prospective inhabitants in rather vague terms as poor but respectable people, but sometimes they were more explicit. Some promised a place to their domestic personnel, who customarily were regarded as more or less part of the family for whom provision had to be made, and with whom ties could be intimate. ${ }^{89}$ In Leiden, throughout the early modern age, wealthy households ${ }^{90}$ had at least one or two domestics. The upper bourgeoisie and the town regents often had more - founder Diderick van Leyden (33 in Appendix Table B), for example, employed seven domestics in $1743 .^{91}$

Often the founder's personnel were assigned specific tasks in the almshouse. Cornelis Sprongh (30), for example, stipulated that his servant and her husband should continue to live in his house, which was to be converted into an almshouse, and act as caretakers of the poor, old women housed there. Almshouse foundations could, thus, act as a form of provision for elderly personnel ${ }^{92}$ and the regents who administered their foundations used them as such. ${ }^{93}$

Stipulations favouring those who shared a founder's religion were more common. In a sense, they too were regarded as a form of family, as in the common phrase 'household members of the faith' (huisgenoten des geloofs). At least one founder, Jan de Latere (11), used this exact phrase in his will. In his case, he meant members of the Dutch Reformed church. ${ }^{94}$ Other founders were more explicit about the expected religious affiliation. Gerrit Franckensz van Hoogmade (15), for example, wrote in his will that 
he founded his almshouse out of his special affection for the Mennonite community to which he belonged..$^{95}$ It is possible that the non-Reformed founders specifically meant to strengthen their communities by providing the elderly members with the means to stay out of the civic, magistratecontrolled institutions, and thus preventing them from lapsing from their faith in favour of the Dutch Reformed regime of these institutions. Some dissenter founders kept conspicuously silent about the desired religious affiliation of almspeople in their wills. Post-Reformation Catholic founders, by appointing trusted Catholics as executor-regents, ensured that their almshouse would, in fact, be open only to Catholics. ${ }^{96}$

The stipulations of the Walloon founders that their almshouses were open to Walloons in particular seem more inspired by another form of bond between founder and inhabitants. Religiously, there was no reason why Walloons should dread being taken into a Dutch Reformed almshouse. Leiden's almshouses and hospitals do not seem to have discriminated against Walloon burghers. ${ }^{97}$ However, the fact that the Walloons had the French language in common and shared a background of migration, especially when that migration had not been entirely voluntary, may have played an important role. Jean Pesijn and Marie de Lannoy (both 23), for example, both came from the area around Lille and, in the 1630s, had migrated to Leiden, where they married. That it was not just church membership that was important to them may be inferred from the precise wording of their statement that their foundation was meant for 'des vieilles gens mariés de la nation Wallonne', that is, for 'old married people of the Walloon nation'. The memorial tablet that was installed over the entrance gate specified, moreover, that the Pesijns wished to give comfort to Walloons driven from their homeland. ${ }^{98}$ Thus, the Walloon almshouses served not just a religious, but also an ethnic community.

A similar sense of solidarity was displayed by Anthonis Jacobsz van der Schacht (24). Orphaned as a boy, he stipulated that, after his family, precedence should be given to former orphans who, like him, had been taken in by the city orphanage. His concern for orphaned children is also apparent from the fact that as a successful 'needle maker' he apprenticed several orphans and bequeathed 1,000 guilders to the orphanage. ${ }^{99}$

Finally, gender solidarity may also have played a role in founding almshouses. Some founders, at least, seem specifically motivated by concern for the vulnerability of single women in society, ${ }^{100}$ such as the wealthy Eva van Hoogeveen (20), who remained unmarried throughout her life though she must have been a desirable match. She was explicitly described in the epithet over the almshouse gate as a "most chaste and laudable virgin', and specified that her almshouse was meant for women 'who had 
no husband'. This wording was rather unusual and suggests that she wanted to provide a home explicitly for confirmed spinsters from less privileged backgrounds than her own. ${ }^{101}$ Another example is Emerentia Benningh (17), who founded the Klein Sionshofje, a small almshouse specifically for four widows of the inhabitants of the adjoining Sionshofje, who suffered a 'double stroke' when their husband died as they not only lost their husbands but also their home and the support provided by the Sionshofje. ${ }^{102}$ Benningh hired the same architect who had built her husband's almshouse, but her own almshouse remained much more modest in scale - even though she could easily have outdone her husband, as she left an estate worth 306,500 guilders. ${ }^{103}$ Clearly, her intentions were limited to specifically assisting the widows of the Sionshofje, in which case four chambers may well have been enough to provide for these bereaved women.

\section{THE IMPORTANCE OF BEING A PATRON}

Regardless of which category of people an almshouse founder had in mind as deserving of alms, every founder seems to have stood in the centre of a circle of dependants for whom he or she was responsible. Kooijmans has recognised this mechanism of patronage in his study of Dutch early modern family and friendship relations. As depicted in Figure 2, the first responsibility that the head of a family had was to his immediate family - including children, sometimes parents, siblings and siblings' children. Beyond that, there was a wider circle of kin, varying from descendants of maternal ancestors to far-removed patrilineal relatives. The head also had responsibility for his domestic personnel, non-domestic personnel and any neighbours with whom he had a long-standing patronage relationship. Looking after these relations reflected positively on the reputation of the head, and on that of his family; failure to look after them would be viewed negatively, as the reputation of the family depended on the proper behaviour of all its members, no matter how far removed. Poverty of one reflected badly on the rest. ${ }^{104}$

This patronage mechanism explains part of the choice of recipients of almshouse charity. For founders, as Figure 3 shows, looking after co-religionists and fellow members of a particular ethnic group was not as obligatory as looking after family members and dependants. However, a founder was expected to assist fellow co-religionists and fellow-countrymen, with whom there were often kinship relations anyway, so that the different circles overlapped in such cases. ${ }^{105}$ Similarly, looking after single or widowed women in general, or former orphans in 


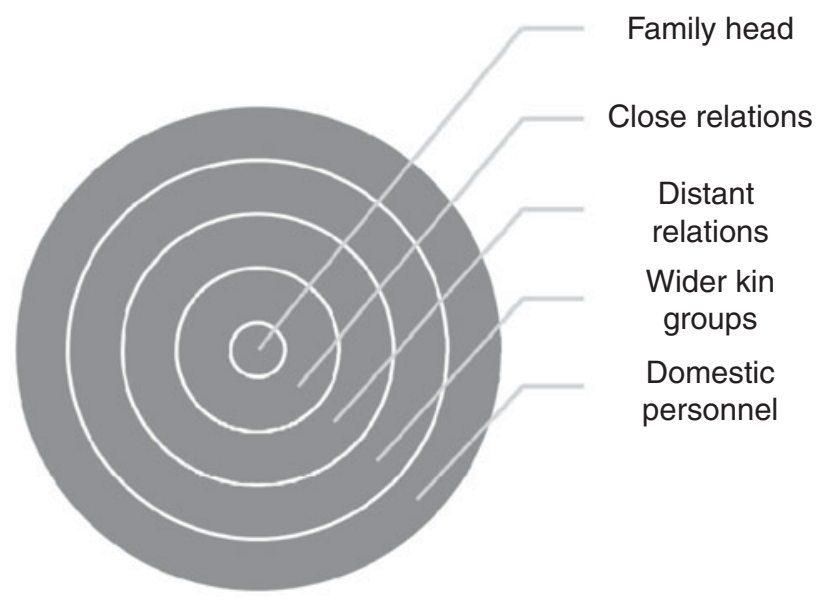

FIgURE 2. Obligations of a Dutch family head.

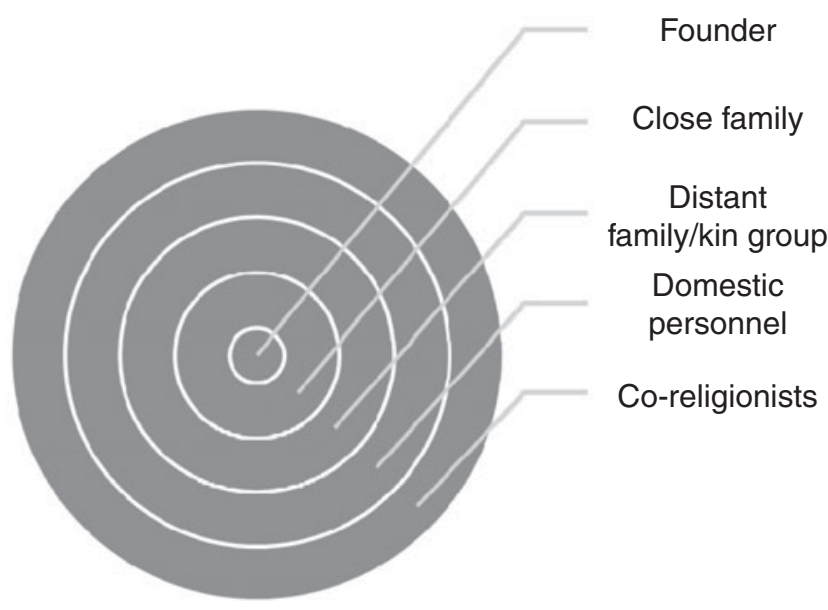

FIGURE 3. Obligations of an almshouse founder.

general, was not ordinarily a task for a family head, but looking after widows, single women and orphans within the family circle certainly was.

Not all founders worked within the same set of circles. Almshouse founders who were extremely wealthy often gave other categories of recipients precedence over their relatives. Thus, Eva van Hoogeveen (20, Appendix Table B) emphasised that her almshouse was meant primarily for single women, and did not specify in her will that her relatives 
had a greater claim over others. ${ }^{106}$ Neither did Diderick van Leyden (33). It was possibly inconceivable to this wealthy burgomaster that his direct family would ever suffer want. In his case, at least one of his almshouses may have catered to another specific group: the inhabitants of his lordships. ${ }^{107}$ This too would have been understood as part of the circle of responsibilities within which a well-to-do Dutch burgher stood. ${ }^{108}$

\section{ALMSHOUSES AS SAFETY VALVES}

Founders' responsibilities defined, to a large extent, the social composition of almshouse populations. Data available on almshouse inhabitants strongly suggest that, apart from the impoverished members of founders' families, most were members of the Dutch Republic's largest social classes.

Dutch historians distinguish five or six layers in early modern Dutch society. Beneath the patricians and nobility was the layer of the "great burghers', which consisted of merchants, ministers and academics, ${ }^{109}$ followed by the layers of 'broad burghers', 'small burghers', the wagedependants, and, in the lowest position, the 'rabble'. The broad and small burghers together formed the 'decent middle class, the cork on which society floated" 110 - the upper and lower middle classes. The "broad burghers' or upper middle class consisted of successful artisans, small entrepreneurs, well-off shopkeepers, lower military officers, urban officials, village ministers and well-off farmers. They formed about 10 per cent of the population and enjoyed an annual income of 600 to 1,000 guilders. Often they could afford to save money for their old age. ${ }^{111}$ The 'small burghers', or lower middle class, formed a heterogeneous group of small farmers, lower officials, schoolmasters, small skippers, small shopkeepers and artisans, many of them dependent on wage labour: this layer was 'above all, the world of small guild masters', who, incidentally, had their own system of welfare. ${ }^{112}$ They formed about a third of the Dutch population, subsisting on an annual income of 350 to 600 guilders. Though regarded as 'respectable', the small burghers did not have many certainties: the early death of the breadwinner, a protracted illness or an accident could easily lead to social degradation in their case.

The same applied to the lower layer of wage-dependants, domestic servants, soldiers and sailors, relatively low-skilled artisans such as textile labourers, ship's carpenters, usually in the service of others, and unskilled labourers organised in guilds, such as the important group of carriers in Amsterdam who loaded and unloaded ships. Like the 'small burghers', their future prospects were uncertain; personal mishap or economic fluctuations could easily tip them into poverty. They subsisted on an annual 
income of 300 to 350 guilders and comprised another third of the population.

These two groups - the lower middle class and the wage-dependants, comprising some 60 per cent of the population - were forever balanced precariously on the threshold between respectability and the rabble. For them, it was much more difficult to save money for their old age. A place in an almshouse allowed them to age with grace and without losing face, that is, without descending into the lowest class of Dutch society, the 10 per cent of the population who could hardly subsist even at the best of times. ${ }^{113}$ Dutch society did not abandon this lowest rung of society, but almshouses often - though not always - excluded the really poor through more or less strict requirements regarding church membership and less easily traceable notions of respectability and decency. In Leiden, at least 25 almshouses in one way or another adhered to such requirements. The 'rabble' simply could not live up to these rules - even if they had been able to save enough money to pay an entrance fee.

Unfortunately, the dearth of sources does not allow a detailed account of who actually lived in Leiden's almshouses. Registers of almshouse inhabitants are rare and, when they do exist, not very informative. Almshouse regents seem to have been more concerned with administrating the almshouse's funds properly. An exception, in this sense, was Pauwels Pauwelsz van Thorenvliet, regent of the Sint Anna Aalmoeshuis between 1604 and 1627, who kept a register of the inhabitants, their ages, names, origins and, sometimes, information on the occupations of their deceased husbands. ${ }^{114}$ These latter had mostly had jobs placing them in the lower middle class and the group of wage-dependants. Three had been active as weavers and two as cloth-millers. The other occupations listed included kettle-smith, knife-smith, corn-measurer, shoemaker, ball-maker, butcher, soldier, tailor, farmer and peat-digger. However there was also a lakenreder or textile-manufacturer/merchant, an occupation with great potential for acquiring wealth.

There are other indications that entering an almshouse was not for the truly poor. In some cases, inventories of the goods that the inhabitants brought with them have been preserved. From these lists, it is clear that almshouse inhabitants were not the poorest since they possessed considerable amounts of furniture, utensils, clothing, some jewellery, money and sometimes a book. The inventories, which were deposited with the regents upon entering, suggest also a moderate amount of literacy, as they were written by the new arrivals themselves.

Almshouses in Leiden, thus, seem to have catered for those for whom old age might mean a loss of goods and status, and, therefore, were predominantly of interest to those who feared their lives would outlast 
their means. This category extended to those from a higher social background. The textile manufacturer's widow is a case in point, as is Van Thorenvliet's cousin, who was admitted to the almshouse in 1622 and was obviously more well-to-do than her new neighbours. ${ }^{115}$ On the whole, however, almshouses primarily catered to the lower middle class and the wage-dependants, from whose ranks most dependants of almshouse founders and regents originated. When no relatives needed a place domestics and outdoor personnel, such as gardeners and washerwomen, came first in line. Similarly, those 'fellows in the faith' who desired a place were also more likely to have come from amongst the ranks of the 'small burghers'. It is probable that most inhabitants originated from these large groups in society. More research is needed before this can be confirmed with greater conviction, but it is perhaps not going too far here to postulate that in almshouses, the top 20 per cent of early modern society provided an escape from the poverty trap for the 60 per cent of the population defined as 'small burghers' and wage-dependants.

\section{CONCLUSION}

The introduction asked who the almshouse founders of Leiden were, and why, and for whom, they founded their almshouses. The prosopography of Leiden's almshouse founders suggests that they were likely to be male and usually married, in which case their wives often acted as co-founders. A minority of the founders consisted of women, most of whom were spinsters or widows. The vast majority of founders in Leiden had been married at some point in their lives, but a considerable majority did not leave children behind at the time of foundation. Religiously, they were mostly conformist. Although before the Reformation, in 1573, they were all Catholic, after that date 21 out of 28 adhered to the Reformed church while Non-Reformed foundations were fewer, but ran most of the religious gamut of the Republic, such as Catholic, Mennonite and Remonstrant. Though theologically in communion with the Dutch Reformed, the Walloon Reformed founders actually formed the largest subdivision, eight founders being from this ethnically defined group. The seven dissenter founders and the eight Walloon founders may, however, have had in common the desire to contribute to the cohesion of their respective religious and ethnic communities.

The wealth of the founders varied, as did the extent to which they used their capital for their foundations but, in all cases, their wealth must have been considerable. The most remarkable change over time was the decrease in founders who were part of the patrician elite. Before 1573, almost all founders occupied positions in the urban government. After 
1573, only three founders did so, though another six founders were part of the urban super-elite. In contrast, 19 post-Reformation founders formed part of the city's rich sub-elite. A possible explanation for this sharp contrast may be that town regents in later eras were responsible for many of the older foundations, which stopped them from founding their own almshouses.

As for why almshouses were founded, Leiden founders could have been motivated by religious concerns. This was clearly attested by the preReformation founders, who expected the inhabitants of their foundations to pray for their souls. After the Reformation, they showed concern for the spiritual welfare of the beneficiaries of their foundation, but, increasingly, they also showed obvious concern for the memory and status of themselves and their families, past and present. Founding an almshouse was a way to acquire or solidify the status of a particular family. The motive of status acquisition may have been highly important to the many founders from the sub-elite. Closely related to this motive was the strong concern for all those for whom they felt, or were obligated to feel, responsible as patrons. Almshouses were founded to accommodate less well-off relatives, personnel, fellow religionists, countrymen, women and former orphans, and in one case, the subjects of their lordships. Most of these recipients could be found in the lower, but not the lowest, regions of Dutch society.

The composite image of the Leiden almshouse founders provided in this article suggests that, though the Dutch charitable institutions seemed 'many and various' to Sir William Temple, in fact, they showed a considerable degree of similarity to one another; as a group, they displayed considerable homogeneity, even across the centuries. Although change certainly occurred, the continuity may, in fact, have been greater. 
A P PENDIX

TABLE A

Leiden almshouse foundations ca. 1450-ca. 1800

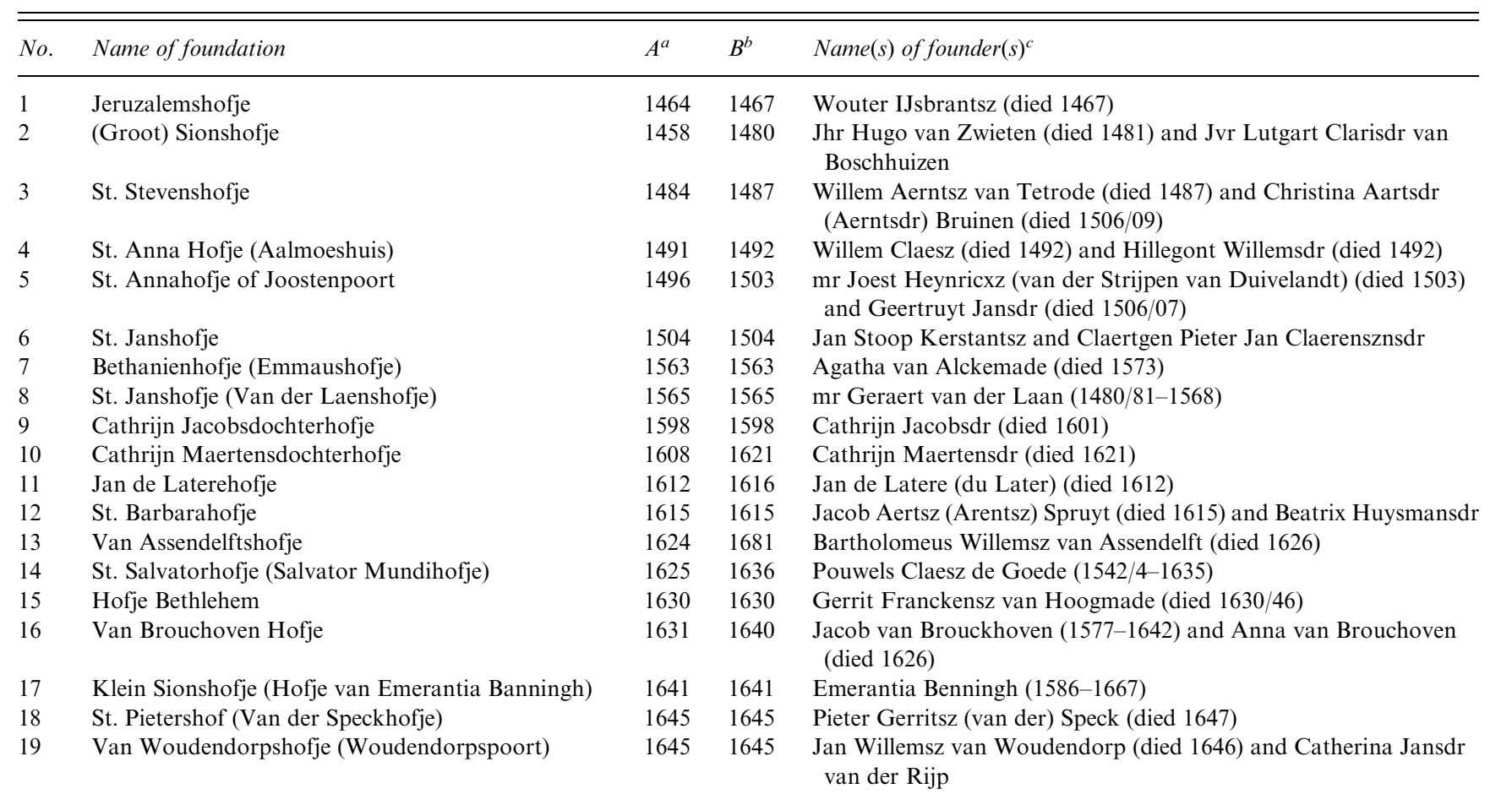


TABLE A (Cont.)

\begin{tabular}{|c|c|c|c|c|}
\hline No. & Name of foundation & $A^{a}$ & $B^{b}$ & Name $(s)$ of founder $(s)^{c}$ \\
\hline 20 & Hofje van Eva van Hoogeveen & 1650 & 1659 & Eva Aelbrechtsdr van Hoogeveen (1594-1652) \\
\hline 21 & Hofje van (Pieter) Loridan & 1655 & 1656 & Pieter Loridan (died 1656) \\
\hline 22 & Tevelingshofje (Karel Tevelshofje) & 1655 & 1666 & $\begin{array}{l}\text { Charles Tevel (died 1660), Jacob Tevel (ca. 1605-1664) and } \\
\text { Elisabeth van den Vinct (died 1667) }\end{array}$ \\
\hline 23 & Jan (Jean) Pesijns Hofje & 1655 & 1681 & Jan Pesijn (died 1666) and Marie de Lannoy (died 1681) \\
\hline 24 & Schachtenhofje & 1664 & 1671 & Anthonis Jacobsz (van der) Schacht (Schaft) (ca. 1613-1669) \\
\hline 25 & $\begin{array}{l}\text { Joost Frans van der Lindenhofje } \\
\text { (Remonstrantenpoort) }\end{array}$ & 1668 & 1691 & Joost Fransz van der Linden (died 1668) \\
\hline 26 & St. Jacobshofje (Crayenboschhofje) & 1672 & 1681 & Gommarus Jacobsz van Crayenbosch (died 1681) \\
\hline 27 & Hofje Meermansburg & & 1680 & $\begin{array}{l}\text { Maarten Ruychaver Meerman (1627-1684) and Helena Verburch } \\
\text { (ca. } 1625 / 1630-1683)\end{array}$ \\
\hline 28 & Francois Houttijnshofje & 1685 & 1736 & Francois Houttijn (died 1688) \\
\hline 29 & Jean Michielshofje & 1687 & 1717 & Jean Michel and Catharina Geschier (died 1691) \\
\hline 30 & $\begin{array}{l}\text { Heilige Geesthofje (Hof van Cornelis Sprongh } \\
\text { van Hoogmade) }\end{array}$ & 1690 & 1706 & Cornelis Sprongh (1642-1706), heer van Hoogmade \\
\hline 31 & Hofje van Samuel de Zee & 1723 & 1724 & Samuel de Zee (Samuel le Maire) (1654-1724) \\
\hline 32 & Barend van Namenshofje & 1728 & 1730 & Barend van Namen (died 1729) \\
\hline 33 & Mierennesthofje & 1737 & 1737 & mr Diderick rijksgraaf van Leyden $(1695-1764)$ \\
\hline 34 & Coninckshofje & 1758 & 1773 & Cecilia Coninck (died 1771) \\
\hline
\end{tabular}

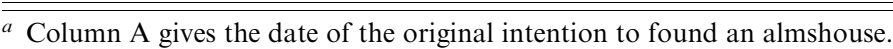

${ }^{b}$ Column B gives the date of the actual effectuation of the foundation.

${ }^{c}$ It is a Dutch convention to abbreviate surnames so, for example, Jacobsz (no. 25) is a shortened version of Jacobszoon and Jacobsdr (no. 9) is a shortened version of Jacobsdochter.

Source: Dutch Almshouse Database. 
TABLE B

Characteristics of the founders

\begin{tabular}{|c|c|c|c|c|c|c|c|c|}
\hline No. & Names of founders ${ }^{a}$ & Gender & $\begin{array}{l}\text { Marital } \\
\text { status }^{b}\end{array}$ & Offspring & Occupation & $\begin{array}{l}\text { Patrician } \\
\text { rank }^{c}\end{array}$ & $\begin{array}{l}\text { Walloon/Southern } \\
\text { Netherlands } \\
\text { background }\end{array}$ & Religion $^{d}$ \\
\hline 1 & Wouter IJsbrantsz (died 1467) & Male & M & Childless & $\begin{array}{l}\text { Grocer and cloth } \\
\text { merchant }\end{array}$ & Alderman & & $\mathrm{C}$ \\
\hline 2 & $\begin{array}{l}\text { Jhr Hugo van Zwieten (died } \\
\text { 1481) and Jvr Lutgart Clarisdr } \\
\text { van Boschhuizen }\end{array}$ & Male/female & $\mathrm{M}$ & Childless & $\begin{array}{l}\text { Nobleman and } \\
\text { landed proprietor }\end{array}$ & Burgomaster & & $\mathrm{C}$ \\
\hline 3 & $\begin{array}{l}\text { Willem Aerntsz van Tetrode } \\
\text { (died 1487) and Christina } \\
\text { Aartsdr (Aerntsdr) Bruinen } \\
\text { (died 1506/09) }\end{array}$ & Male/female & M & Childless $^{\mathrm{e}}$ & $\begin{array}{l}\text { Brewer and cloth } \\
\text { merchant }\end{array}$ & & & $\mathrm{C}$ \\
\hline 4 & $\begin{array}{l}\text { Willem Claesz (died 1492) and } \\
\text { Hillegont Willemsdr (died } \\
\text { 1492) }\end{array}$ & Male/female & M & Children & Brewer and barber & Alderman & & $\mathrm{C}$ \\
\hline 5 & $\begin{array}{l}\text { mr Joest Heynricxz (van der } \\
\text { Strijpen van Duivelandt) (died } \\
\text { 1503) and Geertruyt Jansdr } \\
\text { (died } 1506 / 07 \text { ) }\end{array}$ & Male/female & M & Children & Apothecary & Burgomaster & & $\mathrm{C}$ \\
\hline 6 & $\begin{array}{l}\text { Jan Stoop Kerstantsz and } \\
\text { Claertgen Pieter Jan } \\
\text { Claerensznsdr }\end{array}$ & Male/female & M & Childless & Brewer and dyer & Burgomaster & & $\mathrm{C}$ \\
\hline 7 & $\begin{array}{l}\text { Agatha van Alckemade (died } \\
\text { 1573) }\end{array}$ & Female & $\mathrm{W}$ & Children & $\begin{array}{l}\text { Noblewoman and } \\
\text { landed proprietor }\end{array}$ & & & $\mathrm{C}$ \\
\hline
\end{tabular}


TABLE B (Cont.)

\begin{tabular}{|c|c|c|c|c|c|c|c|c|}
\hline No. & Names of founders ${ }^{a}$ & Gender & $\begin{array}{l}\text { Marital } \\
\text { status }^{b}\end{array}$ & Offspring & Occupation & $\begin{array}{l}\text { Patrician } \\
\text { rank }^{c}\end{array}$ & $\begin{array}{l}\text { Walloon/Southern } \\
\text { Netherlands } \\
\text { background }\end{array}$ & Religion $^{d}$ \\
\hline 9 & Cathrijn Jacobsdr (died 1601) & Female & $\mathrm{W}$ & $\begin{array}{l}\text { No known } \\
\text { children }\end{array}$ & Tailor's widow & & & $\mathrm{NH}^{f}$ \\
\hline 10 & $\begin{array}{l}\text { Cathrijn Maertensdr (died } \\
\text { 1621) }\end{array}$ & Female & $\mathrm{W}$ & $\begin{array}{l}\text { No known } \\
\text { children }\end{array}$ & Tailor's widow & & & $\mathrm{NH}^{g}$ \\
\hline 12 & $\begin{array}{l}\text { Jacob Aertsz (Arentsz) Spruyt } \\
\text { (died 1615) and Beatrix } \\
\text { Huysmansdr }\end{array}$ & Male/female & M & Childless $^{\mathrm{h}}$ & & & & $\mathrm{C}$ \\
\hline 13 & $\begin{array}{l}\text { Bartholomeus Willemsz van } \\
\text { Assendelft (died 1626) }\end{array}$ & Male & $\mathrm{W}$ & Children $^{\mathrm{i}}$ & Wood merchant & Veertigraad ${ }^{j}$ & & NH \\
\hline $16 b$ & $\begin{array}{l}\text { Anna van Brouckhoven } \\
\text { (died 1626) }\end{array}$ & Female & $\mathrm{W}$ & Childless & $\begin{array}{l}\text { Widow of Councillor } \\
\text { Court of Holland }\end{array}$ & & & NH \\
\hline 17 & $\begin{array}{l}\text { Emerentia Benningh } \\
(1586-1667)\end{array}$ & Female & M & Childless & Wife burgomaster & & & NH \\
\hline 18 & $\begin{array}{l}\text { Pieter Gerritsz (van der) Speck } \\
\text { (died 1647) }\end{array}$ & Male & $\mathrm{W}$ & $\begin{array}{l}\text { No known } \\
\text { children }\end{array}$ & Carpenter-architect & & & NH \\
\hline
\end{tabular}




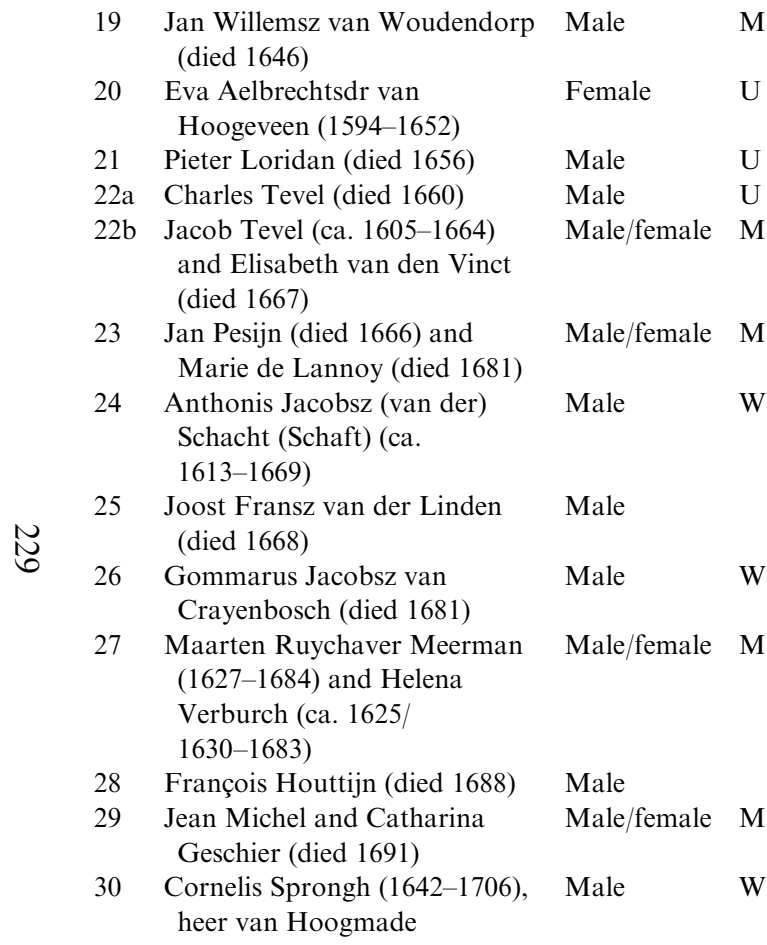

No known Grain merchant

NH

children

Childless Regent's daughter

NH

Childless Cloth dyer

Childless Merchant

Yes

Children $^{\mathrm{k}}$ Merchant

Yes

WH

WH

WH and Elisabeth van den Vinct

(

$\begin{array}{ll}\begin{array}{ll}\text { Children } \\ \text { predeceased }\end{array} & \text { Merchant } \\ \text { Childless } & \text { Shopkeeper }\end{array}$

WH

predeceased

Chilless

Yes

Yes

$\begin{array}{ll}\begin{array}{l}\text { Children } \\ \text { predeceased }\end{array} & \text { Merchant } \\ \begin{array}{l}\text { Children } \\ \text { predeceased }\end{array} & \begin{array}{l}\text { Director of Dutch } \\ \text { East India } \\ \text { Company }\end{array} \\ \begin{array}{ll}\text { Children } & \text { Lawyer } \\ \text { No known } \\ \text { children }\end{array} & \text { Cloth merchant } \\ \text { Childless } & \text { Landed proprietor }\end{array}$


TABLE B (Cont.)

\begin{tabular}{|c|c|c|c|c|c|c|c|c|}
\hline No. & Names of founders ${ }^{a}$ & Gender & $\begin{array}{l}\text { Marital } \\
\text { status }^{b}\end{array}$ & Offspring & Occupation & $\begin{array}{l}\text { Patrician } \\
\text { rank }^{c}\end{array}$ & $\begin{array}{l}\text { Walloon/Southern } \\
\text { Netherlands } \\
\text { background }\end{array}$ & Religion $^{d}$ \\
\hline 31 & $\begin{array}{l}\text { Samuel de Zee (Samuel le } \\
\text { Maire) (1654-1724) }\end{array}$ & Male & & $\begin{array}{l}\text { Children } \\
\text { predeceased }\end{array}$ & & & Yes & WH \\
\hline 32 & Barend van Namen (died 1729) & Male & & $\begin{array}{l}\text { Children } \\
\text { predeceased }\end{array}$ & Merchant & & & NH \\
\hline 33 & $\begin{array}{l}\text { mr Diderick rijksgraaf van } \\
\text { Leyden }(1695-1764)\end{array}$ & Male & M & Children & $\begin{array}{l}\text { Administrator and } \\
\text { landed proprietor }\end{array}$ & Burgomaster & & NH \\
\hline 34 & Cecilia Coninck (died 1771) & Female & $\mathrm{U}$ & Childless & & & & NH \\
\hline
\end{tabular}

$\overline{{ }^{a} \text { It is a Dutch convention to abbreviate surnames so, for example, Aerntsz (no. 3) is a shortened version of Aerntszoon and Aerntsdr (no. 3) is a }}$ shortened version of Aerntsdochter.

${ }^{b} \mathrm{M}$, married; W, widowed; U, unmarried.

${ }^{c}$ Only the highest rank attained is mentioned; all men with offices were Leiden patricians.

${ }^{d}$ C, Catholic; NH, Dutch Reformed; WH, Walloon Reformed; M, Mennonite; Rem, Remonstrant.

${ }^{e}$ The marriage was childless, but the husband had an illegitimate daughter.

${ }^{f}$ From the fact that she entrusted the huiszittenmeesters with her foundation, it is clear that this founder was not a dissenter, even if not an avid Calvinist.

${ }^{g}$ As previous footnote.

${ }^{h}$ Jacob Aertsz Spruyt had a child from a previous marriage, who predeceased him.

${ }^{i}$ Bartholomeus Willemsz van Assendelft stipulated in his will that if his daughter were to die without descendants, an almshouse should be built; Regionaal Archief Leiden (RAL), Arch. 513, no. 572. This eventuality took place and resulted in the foundation of the Hofje van Assendelft in 1681.

${ }^{j}$ A 'veertigraad' was a member of the 'Forty', the municipal council, which consisted of 40 members.

${ }^{k}$ Their only surviving son was mentally handicapped and died in 1671 .

${ }^{l}$ Houttijn had a daughter and stipulated that after her death, an almshouse should be founded.

Sources: Dutch Almshouse Database; RAL, Hofjes, passim; RAL, Old Notary Archives. 


\section{A C K NOWLEDGEMENTS}

I am much indebted to my colleagues Lex Heerma van Voss, Marco H. D. van Leeuwen, Elise van Nederveen Meerkerk, Ariadne Schmidt and Daniëlle Teeuwen, the anonymous peer reviewers and the participants of the GIGA sessions at the 8th European Social Science History Conference (Ghent, 13-16 April 2010) for their useful suggestions. The research for this article was made possible by the financial support of the Netherlands Organisation for Scientific Research (NWO).

\section{ENDNOTES}

1 Sir William Temple, Observations upon the United Provinces of the Netherlands, second edition (London, 1673), 170-1; consulted on Early English Books Online (subscription website http://eebo.chadwyck.com/home).

2 For an overview of hospitals, see Ton Kappelhof, 'Hospitäler in den Niederlanden in den frühen Neuzeit (1530-1820)', Mitteilungen des Instituts für Österreichische Geschichtsbeforderung 115 (2007), 312-42. Orphanages: S. Groenveld, J. J. H. Dekker, Th. R. M. Willemse and J. Dane eds., Wezen and Boefjes. Zes eeuwen zorg in wees-en kinderhuizen (Hilversum, 1997). Madhouses: the Zinnelooshuis Reinier van Arkel in Den Bosch, founded in 1442 by Reinier van Arkel and the Willem Arntzstichting in Utrecht, founded in 1461 by Willem Arntz. Both institutions still exist; H. van Rooy, Het gesticht 'Reinier van Arkel' te 's-Hertogenbosch (Den Bosch, 1928); L. Hut, J. de Lange, H. Loois, A. Poslavski and B. van der Woord, De Willem Arntsz Stichting 1461-1961 (Utrecht, 1961); A. Kappelhof, Reinier van Arkel 1442-1992. De geschiedenis van het oudste psychiatrisch ziekenhuis van Nederland (Den Bosch, 1992). Reformatory: A. Hallema, 'De stichting en inrichting van het Utrechtse tuchthuis', Jaarboekje van Oud-Utrecht 3 (1926), 136-59.

3 For England, see Brian Howson, Houses of noble poverty (Ashford, 1993); and Brian Howson, Almshouses. A social and architectural history (Stroud, 2008). There are no general histories available for other countries, though for some cities overviews exist, such as Bruges in Belgium and Lübeck in Germany; Hilde de Bruyne, De Godshuizen in Brugge (Bruges, 1994); and Rainer Andresen, Lübeck. Wohngänge und Stiftshöfe (Lübeck, 1992). For Dublin, see Robert Gahan, 'Old alms-houses of Dublin', Dublin Historical Record 5, 1 (1942), 15-40; and for Denmark, see H. R. Hiort-Lorenzen and E. Rosendahl, Repertorium over legater og milde stiftelser i Danmark (Copenhagen, 1903). The notion that almshouses are a European phenomenon was confirmed and developed in a conference co-organised by the author, Almshouses in Europe from the late middle ages to the present-comparisons and peculiarities, held in Haarlem, the Netherlands, 7-9 September 2011. Some of the papers will be published in a special issue of the Scandinavian Economic History Review 60, 1 (2013).

4 The study of the history of almshouses, though everywhere still marginal, is perhaps strongest in England and the Netherlands, where awareness of their existence is greater than in other European countries. For England, see a forthcoming book, to be published by the Family and Community History Research Society: Nigel Goose, Anne Langley and Helen Caffrey eds., The English almshouse c. 1500-1900 (forthcoming). The great interest in almshouses in the Netherlands is attested by colourful illustrated popular overviews such as D. P. M. Graswinckel, Nederlandsche Hofjes (Amsterdam, 1943); R. Lopes Cardozo, Hofjes in Nederland (Hilversum, 1977); and I. Dorren, Langs hofjes: routes in Nederland en België (Utrecht, 1994). For recent scholarly work, 
Willemijn Wilms Floet of Delft University is working on a dissertation on the architecture of almshouses. For the nineteenth century, almshouses are discussed in M. H. D. van Leeuwen, Logic of charity. A simple model applied to Amsterdam 1800-1850 (Aldershot and New York, 2000).

5 Although far behind Amsterdam and The Hague, the first- and second-richest cities; Kees Zandvliet, De 250 rijksten van de Gouden Eeuw. Kapitaal, macht, familie en levensstijl (Amsterdam, 2006), XXIV.

6 Jan Jansz Orlers, Beschrijvinge der Stadt Leyden (Leiden, 1641), 142-58; and Frans van Mieris, Beschryving der stad Leyden (Leiden, 1762), 246-362. Van Mieris included lengthy extracts from founders' wills. For the importance of wills in charitable giving, see Elise van Nederveen Meerkerk's contribution to this issue of Continuity and Change, 'The will to give: charitable bequests and community building in the Dutch Republic, c. $1600-1800$ '.

7 To give a few examples: H. M. Turck, Die Leidener Wohnstiftungen vom 15. bis 17. Jahrhundert (Aix-la-Chapelle, 1989); Ine Leermakers and Wietske Donkersloot, Wonen om Gods wille in Leidse hofjes (Leiden, 2007); José Niekus and Cor Smit, Van bouwvallig nest tot bijzondere huisvesting. 350 jaar Jean Pesijnhof (Leiden, 2005); and Frits Boersma and Greet Dusseldorp-Kingma, Regenten en kuise maagden. 350 jaar Eva van Hoogeveenshofje (Leiden, 2007). Of great importance are also the many articles and special issues published by, among others, archivist P. J. M. de Baar in the journal De Leidse Hofjes (1969-1985).

8 They will therefore here be left out of the corpus of almshouse founders. They include the Heyn Reynszn. Huys (ca. 1429), Willem Danelszs cloester (before 1451 and after 1487), Cameren van Katherijn van der Hoeven (ca. 1478) and the Camertgen van Lijsbeth van Overwael (ca. 1485). The house of Meyne Uyt den Waerd (1368) and the chambers of Jan Arentsz van Beringen (1511) may never have come into existence. The Pieter Simonsz Zusterhuis, founded in 1389, may never have been an almshouse and developed quickly into a beguinage, a congregation of devout laywomen. Another short-lived foundation was the Warnaer van der Does Hof, founded in 1564 but already closed down by 1592; information from the Dutch Almshouse Database (hereafter DAD).

9 See J. K. S. Moes, 'Stof uit het Leidse verleden. Sociale en economische facetten uit de geschiedenis van de Leidse textielnijverheid ca. 1275-ca. 1975', in J. K. S. Moes and B. M. A. de Vries, Stof uit het Leidse verleden. Zeven eeuwen textielnijverheid (Utrecht and Leiden, 1991), 7-31, for an overview of the textile trade in Leiden and its periods of growth and decline.

10 As was the case with Zwolle: Elise van Nederveen Meerkerk, 'Geven na de dood. Liefdadige giften en stedelijke geefcultuur in Utrecht en Zwolle, 1600-1800', Stadsgeschiedenis 5 (2010), 129-47, here 137. See also Turck, Die Leidener Wohnstiftungen, 7. On the growing poverty in Leiden, see H. A. Diederiks, D. J. Noordam and H. D. Tjalsma eds., Armoede en sociale spanning. Sociaal-historische studies over Leiden in de achttiende eeuw (Hilversum, 1985), passim; G. P. M. Pot, Arm Leiden. Levensstandaard, bedeling en bedeelden, 1750-1854 (Hilversum, 1994), passim.

11 On migration to Amsterdam and overseas as a safety valve for the charitable system of the Dutch Republic, see M. H. D. van Leeuwen, 'Overrun by hungry hordes? Migrants' entitlements to poor relief in the Netherlands, 16th-20th centuries', in S. Hindle and A. Winter, Migration, settlement and belonging in Europe, 1500-2000: a comparative perspective. Berghahn Publishers, in press.

12 The preceding paragraphs are based on DAD; the articles concerning Leiden almshouses in De Leidse Hofjes; Turck, Die Leidener Wohnstiftungen; Leermakers and 
Donkersloot, Wonen om Gods wille; Boersma and Dusseldorp-Kingma, Regenten en kuise maagden; Niekus and Smit, Van bouwvallig nest.

13 Anouk Janssen, Grijsaards in zwart-wit. De verbeelding van de ouderdom in de Nederlandse prentkunst (1550-1650) (Zutphen, 2007), 23-5, 46-7.

14 Harry F. M. Peeters, 'De levensloop in het begin van de Moderne Tijd (1500-1700)', in H. F. M. Peeters and F. J. Mönks eds., De menselijke levensloop in historisch perspectief (Assen and Maastricht, 1986), 59-83, especially 80-1. It is not clear on which he bases his estimate, though he refers to 'demographical computations'.

15 Arie van Deursen, 'De oude dag in een Hollands dorp', in Harald Hendrix and Riet Schenkeveld-van der Dussen eds., Oud en lelijk. Ouderdom in de cultuur van de Renaissance (Amsterdam, 1996), 73-83, here 74.

16 Marco H. D. van Leeuwen and James E. Oeppen, 'Reconstructing the demographic regime of Amsterdam 1681-1920', in Economic and Social History in the Netherlands 5 (1993), 61-102, here 88-9.

17 D. J. Noordam, Leven in Maasland. Een hoogontwikkelde plattelandssamenleving in de achttiende en het begin van de negentiende eeuw (Hilversum, 1987), 78-9.

18 Janssen, Grijsaards in zwart-wit, 26; Ronald Sluijter, 'Oud, afgesloofd, behoeftig en arm. Bejaardenzorg in Leiden in de achttiende eeuw' (unpublished M.A. thesis, University of Leiden, 1995). I am indebted to Dr Ariadne Schmidt for this reference.

19 The percentages mentioned here are calculated on the basis of Table 10 in van Leeuwen and Oeppen, 'Reconstructing the demographic regime', 88-9.

20 Only for emigrants from Leiden in the years 1735-1784, but one may doubt if the number of elderly emigrants is representative, assuming that most elderly people would not be very mobile anymore; on the age division of emigrants from Leiden, see C. A. Davids, 'De migratiebeweging in Leiden in de achttiende eeuw', in Diederiks, Noordam and Tjalsma, Armoede en sociale spanning, 137-56, here 148.

21 The term 'functioning' is defined as foundations that had actually been put into effect. Some Leiden foundations did not take effect until long after the actual foundation, as Table B in the Appendix shows.

22 H. D. Tjalsma, 'Een karakterisering van Leiden in 1749', in Diederiks, Noordam and Tjalsma, Armoede en sociale spanning, 17-44, here 33; personal communication Heiko Tjalsma M.A., 8 November 2011.

23 Sluijter arrives at a similar number of elderly almshouse inhabitants - 500 - on the basis of the same data, although he believes that this value is probably too high; Sluijter, 'Oud, afgeleefd, behoeftig en arm', 15-16.

24 Sluijter gives the following figures for elderly Leiden inhabitants enjoying social care in 1749: elderly individuals with a separate household receiving poor relief: 300 ; almshouse inhabitants: 500; elderly people living with family: 100; elderly people lodged with private carers: 300 ; hospital inhabitants: 300 ; a total of about 1,500; Sluijter, 'Oud, afgeleefd, behoeftig en arm', 20-1.

25 For a discussion on the possibilities and pitfalls of prosopography as a method, see Lawrence Stone, 'Prosopography', Daedalus. Historical Studies Today 100 (1971), 46-79. Prosopography as a method has flourished in the Netherlands since its introduction in the late 1970s. Two studies of the early modern Leiden patrician elite, frequently cited in this article, are products of this Dutch interest in prosopography; D. J. Noordam, Geringde buffels en heren van stand. Het patriciaat van Leiden, 1574-1700 (Hilversum, 1994); Maarten Prak, Gezeten burgers. De elite in een Hollandse stad 1700-1780 (Amsterdam, 1985). For an overview of Dutch and Belgian work using prosopography as a method, see Koen Goudriaan, Kees Mandemakers, Jogchum Reitsma and Peter Stabel eds., Prosopography and computer. Contributions of 
mediaevalists and modernists on the use of the computer in historical research (Leuven and Apeldoorn, 1995).

26 This is because two less obvious combinations of founders have been listed separately. In one case, a brother and sister - Jacob and Anna van Brouckhoven - were involved and in the other, two siblings and one in-law: the Tevelingshofje was founded by a pair of brothers and the wife of one of them, and thus had three founders. Whenever an almshouse, however, was founded by husband and wife jointly, they have been counted as one founder. Marriage law valid in Leiden stipulated that a husband had control of his wife's capital and acted on her behalf throughout their married life: Ariadne Schmidt, Overleven na de dood. Weduwen in Leiden in de Gouden Eeuw (Amsterdam, 2001), ch. 3 and 4.

27 Not all Leiden almshouses could be taken into account. The Houcksteen almshouse, founded in 1660, was not founded by a private benefactor but by the deaconry of the Flemish Mennonite congregation. Also excluded is the Elisabethgasthuishof which did not originate as an almshouse but as a hospital, developed into an institution housing corrodians and only much later, in the eighteenth century, developed into an almshouse. Originally founded by private benefactors in 1428, its different aims and administrative history make this almshouse a borderline case.

28 See Manon van der Heijden, Elise van Nederveen Meerkerk and Ariadne Schmidt, 'Terugkeer van het patriarchaat? Vrije vrouwen in de Republiek', Tijdschrift voor Sociale en Economische Geschiedenis 6, 3 (2009), 26-52.

29 Again, founding couples constitute one founder.

30 When the founder was a couple, absence or presence of children is related to them as a unit. However, in two cases the husbands had had children by a woman other than his current wife: Jacob Spruyt had a predeceased child from a previous marriage, whereas Willem Aerntsz van Tetrode had an illegitimate child; DAD.

31 Noordam, Geringde buffels, 93-4; van Nederveen Meerkerk comes to a similar conclusion: in Utrecht and Zwolle a significant proportion of donors did not have children, at least when compared with testators as a whole and with general demographic patterns; Van Nederveen Meerkerk, 'Geven na de dood', 141-2. See also her contribution to this issue: 'The will to give'.

32 Regional Archive Leiden (hereafter RAL), Arch. 513 (Hofjes), no. 572, Will of Bartholomeus Willemsz van Assendelft, 29 September 1624.

33 To name two examples: Diderick van Leyden was survived by five adult sons and Geraert van der Laen's lineal descendants were still involved in his almshouse in the nineteenth century; Prak, Gezeten burgers, 396-8; Leermakers and Donkersloot, Wonen om Gods wille, 130-45.

34 See Prak, Gezeten burgers, 75, 170-1, 207, 245-8.

35 P. J. M. de Baar, 'Het Mierennesthofje', De Leidse Hofjes 12 (1983), 1-13; L. J. M. Bovée, 'Het van Leydenshofje te Vlaardingen', De Leidse Hofjes 12 (1983), 14-18.

36 For this problem, see Marco H. D. van Leeuwen, 'Giving in early modern history: philanthropy in Amsterdam in the Golden Age', in this issue of Continuity and Change.

37 This was the case with the Sionshofje, the St. Stevenshofje, the St. Annahofje (Joostenpoort), St. Janshofje, Cathrijn Jacobsdochterhofje, the St. Barbarahofje, the Cathrijn Maertensdochterhofje, the Van Assendelfthofje and the Van Woudendorphofje; DAD.

38 RAL, Stadsarchief van Leiden II, 1574-1816 (hereafter SA II) 6177, will Cathrijn Maertensdr, 17 February 1621; Arch. 513 (Hofjes), no. 425, will Pieter Gerritsz van der Speck, 7 August 1645.

39 Boersma and Dusseldorp-Kingma, Regenten en kuise maagden, 20, 69. 
40 de Baar, 'Het Mierennesthofje', 4, 8.

41 R. E. O. Ekkart, 'Het Coninckshofje 1773-1973', De Leidse Hofjes 2 (1973), 11-22, here 11.

42 Noordam, Geringde buffels, 89, 93.

43 R. E. O. Ekkart, 'Cornelis Sprongh en zijn hofje aan de Breestraat', De Leidse Hofjes 3 (1974), 29-36, 34; Prak, Gezeten burgers, 282.

44 Niekus and Smit, Van bouwvallig nest, 24, 29.

45 Prak, Gezeten burgers, 117.

46 These figures obscure a difference: of the rich burghers, Prak took only the richest Leiden inhabitants into account, whereas the town regents as a group included a number of not so wealthy members, lowering the average income; the median incomes of the merchants/entrepreneurs, Protestant rentiers and Catholics were 193,731, 166,107 and 130,111 guilders. He compared them with the town regents whose capital was over 100,000 guilders, and then arrived at figures of an average income of 225,274 guilders, and a median of 174,165 guilders, which shows a smaller difference between the city's regent- and non-regent elite; Prak, Gezeten burgers, 131-2.

47 Not an occupation as such, but an assumption, based on secondary literature, of the founder's particular main economic activity and mainstay.

48 This term is used here to classify men whose primary occupation was a position in administration.

49 RAL, Arch. 513, no. 545, probate inventory Anthonis Jacobsz van der Schacht, 17 March 1670. See also Th. J. Lunsingh Scheurleer, C. Willemijn Fock and A. J. van Dissel, Het Rapenburg. Geschiedenis van een Leidse gracht, volume I (Leiden, 1986), 233, 238.

50 The phrase 'regent' was used for everyone who held an urban office of some sort: I distinguish here between the town regents, the patrician men who had a seat on the town council and stood at the apex of urban society, and almshouse regents, the men - and sometimes women - who sat on the almshouse boards.

51 Incidentally, this concurs with some of the conclusions that Van Nederveen Meerkerk draws; 'The will to give'.

52 Noordam, Geringde buffels, 35; Prak, Gezeten burgers, 75, 170-1, 207.

53 Willem Aerntsz van Tetrode did not fill any offices either, but he also belonged to the patrician elite of Leiden; Leermakers and Donkersloot, Wonen om Gods wille, 86-7.

54 See also Noordam, Geringde buffels, 93, where it is stressed that in general the founding of an almshouse was exceptional.

55 For the accumulation of capital; Prak, Gezeten burgers, ch. 3; Noordam, Geringde buffels, 94.

56 Van Nederveen Meerkerk, 'The will to give'.

57 Their bequest encompassed about a sixth of their total estate of 133,652 guilders; Prak, Gezeten burgers, 200, 419.

58 RAL, Arch. 513 (Hofjes), 333, list of regents Hofje van Brouckhoven 1642-1857; Prak, Gezeten burgers, 374-8, 383, 386, 389, 391-3, 395-6, 399-403, 408, 414-15, 418.

59 Namely the St. Stevenshofje, the Bethaniënhofje and the Van Brouckhovenhofje; for Van de Velde, see Prak, Gezeten burgers, 418.

60 See, for example, Boersma and Dusseldorp-Kingma, Regenten en kuise maagden, 27, 32 , 35; A. J. Sormani, 'Het Salvatorhofje 1639-1939', Leidsch Jaarboekje 33 (1941), 111-25, 121; P. J. M. de Baar, 'De strijd tussen het St.Annahofje en de gemeente Leiden over de “onlosbare" renten', De Leidse Hofjes 14 (1985), 67-71; Ekkart, 'Het Coninckshofje', 18. For the important role donations to poor relief institutions by its regents played in Amsterdam, see van Leeuwen, 'Giving in early modern history'. 
61 RAL, Arch. 513 (Hofjes), provisional inventory Mierennesthofje, no. 5, will of Diderick van Leyden, 14 June 1760. Obviously, he held two positions at the same time. See also RAL Arch. 513 (Hofjes), Hofje van Brouckhoven, no. 333.

62 See L. Heerma van Voss and M. H. D. van Leeuwen, 'Charity in the Dutch Republic: an introduction', in this issue of Continuity and Change, and also van Leeuwen, 'Giving in early modern history', for these motives as evidenced by inscriptions on Amsterdam almshouses; for the religious and social reasons in appeals to give to collections, see D. Teeuwen, 'Collections for the poor: monetary charitable donations in Dutch Towns, c. 1600-1800', in this issue of Continuity and Change.

63 Leermakers and Donkersloot, Wonen om Gods wille, 158.

64 D. E. H. de Boer, 'Het Sint Stevenshof tot het eind van de 18de eeuw', De Leidse Hofjes 2 (1973), 25-37, here 27; J. P. Zwanenburg, 'Het Sionshofje. Stichting van het gasthuis of Hofje genaemd Syon, binnen de stad Leyden', De Leidse Hofjes 2 (1973), 39-46, here 40; Turck, Die Leidener Wohnstiftungen, 93; Leermakers and Donkersloot, Wonen om Gods wille, 112, 129.

65 Leermakers and Donkersloot, Wonen om Gods wille, 175-6.

66 Sormani, 'Het Salvatorhofje', 116.

67 Ekkart, 'Cornelis Sprongh', 34.

68 See, for this, Van Leeuwen, 'Giving in early modern history'.

69 Noordam, Geringde buffels, 93; Zandvliet, De 250 Rijksten, 238.

70 RAL, Arch. 513 (Hofjes), no. 559, will of Catharina Geschier.

71 RAL, Arch. 513 (Hofjes), Hofje Samuel de Zee.

72 For example, in the case of St. Anna Aalmoeshuis, the chapel became a favourite spot for the regents to exult their lineage and involvement with the almshouse; P. A. Terwen and R. Crèvecoeur, 'De glasvensters van het St. Annahof-kapelletje', in De Leidse Hofjes 14 (1985), 19-42.

73 Sormani, 'Het Salvatorhofje', 116.

74 J. van Nieuwenburg, 'Uit de geschiedenis van het Woudendorphofje', Leids Jaarboekje 55 (1963), 100-14, especially 101.

75 Such as the regents of the Sint-Elisabethgasthuis who placed their coats of arms over the door of their office; Leermakers and Donkersloot, Wonen om Gods wille, 198-9. Particular elaborate examples in a 'non-social' context can still be seen on and near the Keep of Leiden, the remains of the castle that once dominated the city.

76 'Voorwoord', in P. J. M. de Baar, A. J. van Dissel, J. F. Dröge, H. J. M. van der Geest, J. F. Heijbroek, W. Louwrier and G. C. Quispel, Meermansburg, Leidens grootste hofje 1683-1983 (Leiden, 1983), 1.

77 Van Leeuwen notes a similar concern with status as an incentive to found almshouses; 'Giving in early modern history'.

78 For the importance of family reputation in the Dutch Republic, see L. Kooijmans, Vriendschap en de kunst van het overleven in de zeventiende en achttiende eeuw (Amsterdam, 1997), 11-13, 39-41, 61-2, 88, 90, 97, 101-2, 120, 138-9.

79 Namely, the foundations of: Jan de Latere; Pieter Loridan; Charles Tevel (counted as separate from his co-founders, his brother Jacob and his sister-in-law), Jacob Tevel and Elisabeth van den Vinct; Jan Pesijn and Marie de Lannoy; Anthonis Jacobsz Schacht; Catharina Geschier and Jean Michel; and Samuel de Zee; DAD.

80 Noordam, Geringde buffels, 33-4.

81 Turck, Die Leidener Wohnstiftungen, 185.

82 Van Leeuwen, 'Giving in early modern history'; and Van Nederveen Meerkerk, 'The will to give'. Note a similar concern for family in charitable bequests.

83 Leermakers and Donkersloot, Wonen om Gods wille, 163. 
84 Van Nieuwenburg, 'Uit de geschiedenis van het Woudendorphofje', 106-9.

85 I. W. L. Moerman, 'Het Hofje van Samuel de Zee', De Leidse Hofjes 5 (1977), 31-5, here 33.

86 Leermakers and Donkersloot, Wonen om Gods wille, 102; For other examples, see ibid. 95, 138 and 163.

87 'Bouwgeschiedenis van Meermansburg', in de Baar et al., Meermansburg, 4-9, here 6.

88 Leermakers and Donkersloot, Wonen om Gods wille, 138-9, 145.

89 For some concrete examples of this, see Prak, Gezeten burgers, 232-3; and Van Leeuwen, 'Giving in early modern history'.

90 Obviously not all; in 1749 only about 16 per cent of the households employed domestics; H. A. Diederiks, 'Beroepsstructuur en sociale stratificatie in Leiden in het midden van de achttiende eeuw', in Diederiks, Noordam and Tjalsma, Armoede en sociale spanning, 45-67, especially 61.

91 Noordam, Geringde buffels, 52-3; Prak, Gezeten burgers, 231.

92 Although there were alternatives, such as leaving them a bequest or allowing them to remain in their house for a while.

93 See, for example, Boersma and Dusseldorp-Kingma, Regenten en kuise maagden, 29-31, 44-5.

94 RAL, SA II 6177, Will Jan de Latere and Magdalena Vijns, 24 April 1612. For his charitableness, and that of his wife, see also Van Nederveen Meerkerk, 'The will to give'.

95 L.G. le Poole, Bijdragen tot de kennis van het kerkelijk leven onder de Doopsgezinden, ontleend aan het archief der Doopsgezinde Gemeente te Leiden (Leiden, 1905), 51.

96 Catholicism was tolerated, but Catholics were regarded as second-rate citizens and discriminated against in law. They were, for example, forbidden to bequeath to Catholic priests and institutions; Charles H. Parker, Faith on the margins. Catholics and Catholicism in the Dutch Golden Age (Cambridge, MA, 2008).

97 The Elisabethgasthuis - later, an almshouse - between 1608 and 1654 housed a total of 248 widows, including 111 foreigners, of which 101 were widows from the Southern Netherlands; Schmidt, Overleven na de dood, 185. Also in the St. Anna Aalmoeshuishofje in Leiden in the years 1606-1626 inhabitants could come from the Southern Netherlands; A. J. van Dissel, 'Van wege den hoochdringenden noot en uyt sonderlinge gratie. Enkele bewoonsters van het Sint Annahofje in het eerste kwart van de 17de eeuw', De Leidse Hofjes 14 (1985), 11-17.

98 Niekus and Smit, Van bouwvallig nest, 20, 26-7.

99 RAL, Arch. 513, no. 503, Will of Anthonis Jacobsz van der Schacht, 24 September 1664; donatio inter vivos, 7 August 1655; see also Kees van der Wiel, Dit kint hiet Willem. De Heilige Geest in Leiden - 700 jaar vondelingen, wezen en jeugdzorg (Leiden, 2010), 33.

100 Sandra Cavallo, Charity and power in early modern Italy. Benefactors and their motives in Turin, 1541-1789 (Cambridge, 1995), 5, and ch. IV, notices a similar link between female charity and concern about female vulnerability in the late seventeenth century.

101 P. J. M. de Baar, 'Eva Aelbrechtsdr van Hoogeveen en haar familie', De Leidse Hofjes 13 (1984), 61-6; J. F. Dröge, 'De bouwgeschiedenis van het Eva van Hoogeveenshofje', De Leidse Hofjes 13 (1984), 67-81. It has been suggested that she was unhappy with her unmarried state; Boersma and Dusseldorp-Kingma, Regenten en kuise maagden, 15.

102 RAL, Hofjes 6, f. 24; Schmidt, Overleven na de dood, 189.

103 She ranks as no. 134 in Zandvliet, De 250 rijksten, 240.

104 Kooijmans, Vriendschap, 15-17, 20, 27, 30, 39-41, 54-5, 61-4, 79, 116, 134, 143-6. 
105 Such as providing scholarships for promising students of theology; Kooijmans, Vriendschap, 36.

106 RAL, Arch. 513 (Hofjes), no. 459, Will of Eva van Hoogeveen, 4 June 1650.

$107 \mathrm{He}$ destined the almshouse for Dutch Reformed elderly poor in general, but the fact that he had a commemorative tablet installed listing all his lordship titles suggests that the Vlaardingen almshouse was meant to accommodate elderly persons from his lordships; Bovée, 'Het Van Leydenshofje', 14.

108 For the importance of proximity for establishing who received charity, see also Van Nederveen Meerkerk, 'The will to give'.

109 Some historians combine these two layers together, while others separate them: Paul Knevel, 'Een kwestie van overleven. De kunst van het samenleven', in Thimo de Nijs and Eelco Beukers eds., Geschiedenis van Holland. Deel II, 1572 tot 1795 (Hilversum, 2002), 217-54, here 219-20, divides patricians and nobles from the great burghers; Marco H. D. van Leeuwen, De Rijke Republiek. Gilden, assuradeurs en armenzorg 1500-1800, volume I of: Jacques van Gerwen and Marco H. D. van Leeuwen, Zoeken naar zekerheid. Risico's, preventie, verzekeringen en andere zekerheidsregelingen in Nederland 1500-2000 (Amsterdam and Den Haag, 2000), 41-2, combines them. W. Frijhoff and M. Spies, 1650. Bevochten eendracht (Den Haag, 1999), 189-90, use the same six-layer stratification as Knevel, but in contrast, merge the 'great burghers' and the 'broad burghers' instead of the 'broad' and 'small' burghers. Here we chose to follow Knevel and Van Leeuwen.

110 Van Leeuwen, De rijke Republiek, 41.

111 They could, for example, buy their way into a 'proveniershuis', a house in which one was assured of lifelong care, lodging and food after paying a certain sum of money. Many medieval hospitals in fact had become such proveniershuizen; for example, see Gerda Kurtz, Het Proveniershuis te Haarlem (Haarlem, 1979); C. Boschma-Aarnoudse, Sint-Pietershof the Hoorn: bedelnap en preuve, kruisheren en proveniers aan het Dal (Hoorn, 1993).

112 M. H. D. van Leeuwen, 'Guilds and middle-class welfare 1550-1800: provisions for burial, sickness, old age, and widowhood', Economic History Review 65 (2012), 61-90.

113 Knevel, 'Een kwestie van overleven', 220-1, 230-8; van Leeuwen, De rijke Republiek, 24-9, 41-2; Maarten Prak, Gouden Eeuw. Het raadsel van de Republiek (Nijmegen, 2002), 151-5. See van Leeuwen, De rijke Republiek, passim, for the many risks to which early modern Dutchmen were exposed.

114 On registration habits in the Dutch Republic, see Henk Looijesteijn and Marco H. D. van Leeuwen, 'Identity registration in the Dutch Republic', in K. Breckenridge and S. Szreter eds., Registration and recognition. Documenting the person in world history (Oxford, forthcoming), ch. 8.

115 Van Dissel, 'Van wege den hoochdringenden noot', 11-17; appendix 1-XIV, 75-96.

\section{FRENCH AND GERMAN ABSTRACTS}

Financement et fondation d'œuvres de charité privées à Leiden: les hospices et leurs fondateurs, $1450-1800$

Cet essai présente une monographie consacrée aux fondateurs des hospices pour personnes âgées dans la ville hollandaise de Leiden à partir de la fin du Moyen Âge et jusqu'à 1800. On commence par donner une vue d'ensemble des hospices de Leiden et évaluer leur importance pour les personnes âgées. Ensuite l'auteur 
propose une étude prosopographique des fondateurs d'hospice à Leiden et étudie les raisons pouvant expliquer leur démarche individuelle, prenant en compte leur religion, leur statut et le souci qu'ils eurent chacun de porter assistance à une personne qui leur était très proche ou extrêmement chère à leur cœur. Il poursuit par une analyse de la classe sociale des résidents d'hospice. Cet article affirme que, par ces actions charitables destinées aux hospices, les classes supérieures riches et privilégiées de la société hollandaise se sont occupées d'entretenir des membres (éloignés) de leur famille, leurs employés et d'autres personnes devenues à charge, appartenant à leur cercle de clientèle ou patronage et qu'ainsi les hospices pour personnes âgées, dans la pratique, offrirent surtout aux membres de la frange inférieure de la classe moyenne et à tous ceux dont la vie dépendait d'un salaire, une issue respectable à leur pauvreté visible et honteuse.

Gründung und Ausstattung privater Wohlfahrtseinrichtungen: Armenhäuser in Leiden, 1450-1800

Dieser Beitrag präsentiert eine Fallstudie der Gründer von Armenhäusern für ältere Menschen in Leiden im Spätmittelalter und in der Frühen Neuzeit. Zunächst wird ein Überblick über die Leidener Armenhäuser gegeben, wobei auch danach gefragt wird, welche Bedeutung sie für ältere Menschen besaßen. Es folgt eine Prosopographie der Gründer der Leidener Armenhäuser, die auch die Gründe für die Stiftung von Armenhäusern erörtert und vor allem danach fragt, welche Rolle dabei die Religion, der soziale Status und das Anliegen, seine nächsten und liebsten Angehörigen zu versorgen, spielte. Anschließend wird die Sozialstruktur der Insassen von Armenhäusern analysiert. Die Ergebnisse münden in die These, dass die reichen und privilegierten Oberschichten der holländischen Gesellschaft durch die Stiftung von Armenhäusern ihre (entfernten) Familienmitglieder, Beschäftigten und andere Abhängige innerhalb ihres Patronagezirkels versorgten, und dass die Armenhäuser somit in der Praxis vor allem dazu dienten, für die Mitglieder des Kleinbürgertums und der lohnabhängigen Klassen einen ehrenhaften Weg aus der offenen Schande zu eröffnen, die mit der Armut einher ging. 